\title{
Heat-shock protein 40 is the key farnesylation target in meristem size control, abscisic acid signaling, and drought resistance
}

\author{
Andrea Barghetti, ${ }^{1,2,4}$ Lars Sjögren, ${ }^{1,2,4}$ Maïna Floris, ${ }^{1,2}$ Esther Botterweg Paredes, ${ }^{2,3}$ Stephan Wenkel, ${ }^{2,3}$ \\ and Peter Brodersen ${ }^{1,2}$ \\ ${ }^{1}$ Department of Biology, University of Copenhagen, DK-2200 Copenhagen N, Denmark; ${ }^{2}$ Copenhagen Plant Science Center, \\ University of Copenhagen, 1871 Frederiksberg C, Denmark; ${ }^{3}$ Department of Plant and Environmental Sciences, University of \\ Copenhagen, DK-1871 Frederiksberg C, Denmark
}

Protein farnesylation is central to molecular cell biology. In plants, protein farnesyl transferase mutants are pleiotropic and exhibit defective meristem organization, hypersensitivity to the hormone abscisic acid, and increased drought resistance. The precise functions of protein farnesylation in plants remain incompletely understood because few relevant farnesylated targets have been identified. Here, we show that defective farnesylation of a single factorheat-shock protein 40 (HSP40), encoded by the $J 2$ and $J 3$ genes-is sufficient to confer ABA hypersensitivity, drought resistance, late flowering, and enlarged meristems, indicating that altered function of chaperone client proteins underlies most farnesyl transferase mutant phenotypes. We also show that expression of an abiotic stress-related microRNA (miRNA) regulon controlled by the transcription factor SPL7 requires HSP40 farnesylation. Expression of a truncated SPL7 form mimicking its activated proteolysis fragment of the membrane-bound SPL7 precursor partially restores accumulation of SPL7-dependent miRNAs in farnesyl transferase mutants. These results implicate the pathway directing SPL7 activation from its membrane-bound precursor as an important target of farnesylated HSP40, consistent with our demonstration that HSP40 farnesylation facilitates its membrane association. The results also suggest that altered gene regulation via select miRNAs contributes to abiotic stress-related phenotypes of farnesyl transferase mutants.

[Keywords: farnesylation; heat-shock proteins; meristem; abscisic acid; drought resistance; microRNAs; Arabidopsis]

Supplemental material is available for this article.

Received April 29, 2017; revised version accepted November 20, 2017.

Post-translational modification is important for the control of cellular protein activity. Lipid modifications influence the hydrophobicity of proteins and may regulate their membrane association and interactions with other proteins (Wang and Casey 2016). Prenylation, a form of lipidation in which a polyunsaturated farnesyl $\left(\mathrm{C}_{15} \mathrm{H}_{25}\right)$ or geranylgeranyl $\left(\mathrm{C}_{20} \mathrm{H}_{35}\right)$ group is attached to the $\mathrm{C}$-terminal part of target proteins, is particularly widespread in eukaryotic organisms. Protein farnesylation and geranylgeranylation is catalyzed by deeply conserved heterodimeric enzymes that share the same a subunit but have distinct $\beta$ subunits. These enzymes prenylate a Cterminal CaaX motif in target proteins (where a is aliphatic residue, and $\mathrm{X}$ is any residue) by catalysis of thioether bond formation between the prenyl group and the CaaX motif cysteine (Fu and Casey 1999). In plants, the a sub-

\footnotetext{
${ }^{4}$ These authors contributed equally to this work.

Corresponding author: pbrodersen@bio.ku.dk

Article published online ahead of print. Article and publication date are online at http://www.genesdev.org/cgi/doi/10.1101/gad.301242.117.
}

unit of protein prenyl transferases is encoded by the PLURIPETALA (PLP; AT3G59380) gene (Running et al. 2004). Protein farnesyl transferase contains the $\beta$ subunit encoded by ENHANCED RESPONSE TO ABA1 (ERA1; AT5G40280) (Cutler et al. 1996), while the $\beta$ subunit GGB (AT2G39550) confers specificity to protein geranylgeranyl transferase (Johnson et al. 2005).

The biological relevance of protein farnesylation in plants has been elucidated through the recovery of mutant alleles of era1 and plp in several forward genetic screens. Protein farnesylation is implicated in abscisic acid (ABA) signaling because era1 and plp mutants exhibit pronounced hypersensitivity to ABA (Cutler et al. 1996; Running et al. 2004). ABA is required for seed dormancy and restriction of water loss in response to drought. At the

(C) 2017 Barghetti et al. This article is distributed exclusively by Cold Spring Harbor Laboratory Press for the first six months after the full-issue publication date (see http://genesdev.cshlp.org/site/misc/terms.xhtml). After six months, it is available under a Creative Commons License (Attribution-NonCommercial 4.0 International), as described at http://creativecommons.org/licenses/by-nc/4.0/. 
molecular level, ABA perception by pyrabactin resistance (PYR1)-like receptors is linked to activation of a set of protein kinases in the SNF1-related kinase 2 (SnRK2) family by inhibition of a subgroup of protein phosphatase $2 \mathrm{C}$ enzymes (Cutler et al. 2010). SnRK2 kinases, essential for ABA signaling (Fujii and Zhu 2009; Fujita et al. 2009), in turn phosphorylate numerous targets, including transcriptional activators of an ABA-related gene expression program and ion channels implicated in rapid closure of guard cells (Furihata et al. 2006; Geiger et al. 2009; Lee et al. 2009). However, it is not clear at which point protein farnesylation acts in this signaling pathway, since none of its core components contains CaaX motifs at its $\mathrm{C}$ terminus. Despite the lack of understanding of the molecular basis of ABA hypersensitivity in farnesyl transferase mutants, drought-inducible knockdown of ERA1 has been exploited to engineer canola plants with improved performance under drought stress (Wang et al. 2005, 2009).

A recent study showed that loss of farnesylation of the cytochrome P450 CYP85A2, involved in brassinosteroid biosynthesis, leads to increased ABA sensitivity and drought resistance, but the ABA hypersensitivity of cyp $85 a 2$ mutants defective in farnesylation is substantially less severe than that of era1 mutants (Northey et al. 2016). In addition, the CYP85A2 farnesylation site is not conserved in species that exhibit drought resistance upon ERA1 suppression (Northey et al. 2016), strongly suggesting the existence of farnesylation targets other than CYP85A2 with importance for ABA signaling and drought resistance.

In addition to ABA hypersensitivity, several developmental phenotypes have been observed in farnesyl transferase mutants. These include altered phyllotaxis and increased floral organ numbers, both of which may derive from enlarged and disorganized meristems in era 1 and $p l p$ (Running et al. 1998, 2004; Yalovsky et al. 2000). Moreover, farnesyl transferase mutants are late flowering and have a rounder leaf shape. While the effect on leaf shape is probably explained by reduced brassinosteroid biosynthesis due to defective CYP85A2 farnesylation (Northey et al. 2016), the molecular basis of the other phenotypes remains unexplained. Finally, farnesyl transferase mutants show defects in heat tolerance (Wu et al. 2017), in blue light-induced stomatal opening (Jalakas et al. 2017), and in innate immune signaling via several intracellular immune receptors (Goritschnig et al. 2008), but farnesylated targets responsible for these effects have also not been identified. Thus, precise molecular explanations for the many clear phenotypes of farnesyl transferase mutants are largely unknown because the relevant farnesylated proteins remain elusive.

The heat-shock protein 40 (HSP40) isoforms J2 (AT5G22060) and J3 (AT3G44110), two of >100 HSP40 proteins encoded in the Arabidopsis genome, are presumed to be farnesylated because the Atriplex nummularia J3 ortholog ANJ1 can be prenylated in vitro (Zhu et al. 1993) and because orthologs in yeast (Ydj1) and humans (DNAJA1-4) are farnesylated in vivo (Caplan et al. 1992; Kanazawa et al. 1997). HSP40 proteins can initiate a conserved chaperone assembly line that medi- ates conformational changes required for the activity of many native proteins: An HSP40 dimer binds a client protein and triggers ATP hydrolysis in HSP70 to drive formation of a high-affinity HSP70-ADP-client complex (Misselwitz et al. 1998; Hernandez et al. 2002a,b). In turn, the adaptor protein Hop mediates client transfer to HSP90 for final conformational maturation together with a host of HSP90 cochaperones (Johnson et al. 1998; Pratt et al. 2008). Proteins with binding pockets for hydrophobic ligands constitute a well-studied class of clients of the HSP90 assembly line, exemplified by the vertebrate steroid hormone receptors (Picard 2006). In plants, the HSP90 chaperone pathway plays a crucial role in development and immune signaling (Sangster and Queitsch 2005). Known clients include auxin and jasmonate receptors (Zhang et al. 2015; Wang et al. 2016), a class of proteins with hydrophobic binding pockets (Tan et al. 2007; Sheard et al. 2010), as well as intracellular immune receptors and effector proteins of small RNA-guided gene regulation (Hubert et al. 2003; Iki et al. 2010), two classes of multidomain proteins whose functions are associated with extensive conformational changes (Moffett et al. 2002; Elkayam et al. 2012; Schirle et al. 2014).

Similar to farnesyl transferase mutants, $j 3$ knockout mutants exhibit late flowering (Shen et al. 2011) and were shown recently to be weakly hypersensitive to $A B A$ (Salas-Munoz et al. 2016). In addition, altered HSP70 and HSP90 expression confers ABA-hypersensitive inhibition of germination and compromised ABA-induced closure of guard cells (Clement et al. 2011). We therefore hypothesized that farnesylation of $\mathrm{J} 2$ and $\mathrm{J} 3$ may be important for farnesyl transferase mutant phenotypes and show here that the lack of farnesylation specifically of J2 and J3 nearly completely recapitulates many previously described phenotypes of farnesyl transferase mutants. We also show that farnesyl transferase mutants and transgenic lines expressing farnesylation-deficient $\mathrm{J} 3$ fail to express an abiotic stress-related microRNA (miRNA) regulon controlled by the transcription factor SPL7. This regulon includes miR408 (AT2G47015), whose knockout is sufficient to confer drought resistance (Ma et al. 2015). Thus, many important farnesyl transferase mutant phenotypes are due to altered function of client proteins of farnesylated HSP40 or of the HSP70-HSP90 system in general, and defective expression of an abiotic stressrelated miRNA regulon is likely to contribute to the increased drought resistance observed upon loss of protein farnesylation.

\section{Results}

\section{2//3 are farnesylated in vivo}

$\mathrm{J} 2$ and $\mathrm{J} 3$ are $90 \%$ identical at the protein level and share identical putative farnesylation sites (CAQQ) at the $\mathrm{C}$ terminus (Fig. 1A). Inspection of gene expression and coregulation data indicated that $\mathrm{J} 2$ and $\mathrm{J} 3$ are ubiquitously expressed, that they are tightly coregulated, and that $\mathrm{J} 3$ is the major isoform because it is expressed to threefold to fourfold higher levels than J2 (Fig. 1B,C). To establish 
Barghetti et al.

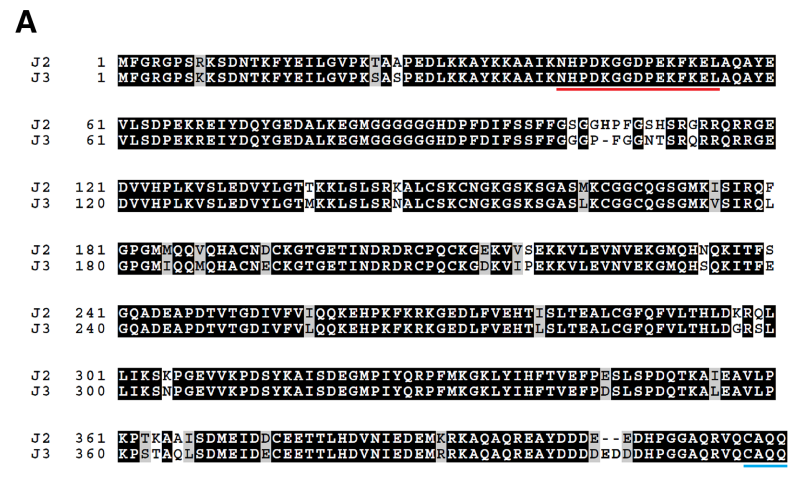

C

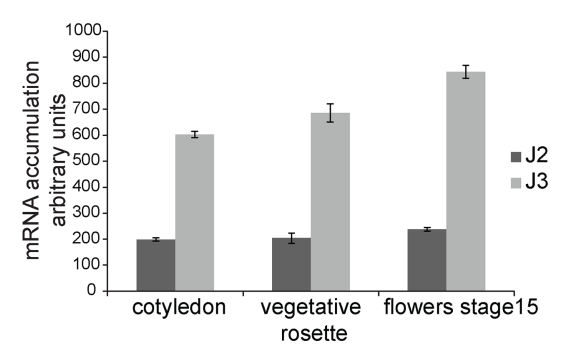

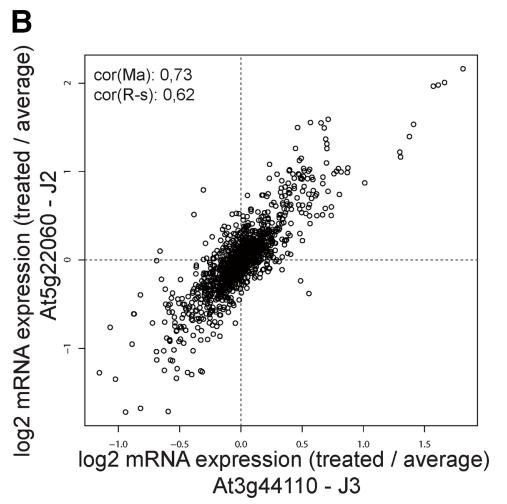

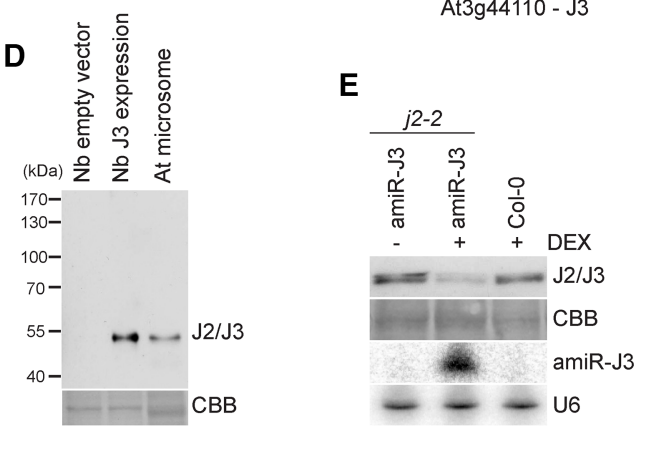

Figure 1. Sequence, expression, and antibody specificity analyses of the closely related CaaX site HSP40 proteins J2 and J3. (A) Alignment of $\mathrm{J} 2$ and $\mathrm{J} 3$ protein sequences. The position of the antigenic peptide is underlined in red, and the C-terminal CaaX motif is underlined in blue. $(B)$ Coregulation of $\mathrm{J} 2$ and J3. The plot shows the $\log _{2}$ values of gene expression ratios (untreated/treated) of J3 (abscissa) and J2 (ordinate) upon a range of abiotic and biotic stress treatments. The plot was generated by the ATTED-II Web server and is based on publicly available microarray and RNA sequencing (RNA-seq) data (Aoki et al. 2016). [Cor(Ma)] Pairwise Pearson's correlation coefficient calculated on the basis of microarray data as described by Obayashi et al. (2007); [cor(R-s)] pairwise Pearson's correlation coefficient calculated on the basis of RNA-seq data. (C) Expression levels of $\mathrm{J} 2$ and $\mathrm{J} 3 \mathrm{mRNA}$ in different tissues. Data were recovered from the Arabidopsis eFP browser (Winter et al. 2007). (D) The J2/J3 antibody recognizes J3 transiently expressed in N. benthamiana leaves. Total lysates of $N$. benthamiana leaves infiltrated with Agrobacteria carrying an empty pEAQ expression vector or pEAQ containing a J3 insert. The third lane contains protein of a microsomal fraction of lysates from Arabidopsis Col-0 seedlings. (E) The J2/J3 antibody is specific. J3 was knocked down by dexamethasone (DEX)-inducible amiR-J3 in a j2-2 knockout background (see Supplemental Fig. S1). Seedlings were germinated on dexamethasone-containing medium and harvested after $16 \mathrm{~d}$ of growth. Microsome fractions were analyzed by Western blot with the J2/J3 antibodies, and total RNA fractions were analyzed by small RNA Northern blot with probes detecting amiR-J3 and U6. The same membrane was used for consecutive hybridizations with probes complementary to amiR-J3 and U6.

that J2/J3 are farnesylated in vivo, we first raised polyclonal J2/J3 antibodies recognizing a peptide identical in J2 and J3 (Fig. 1A). Two approaches demonstrated the specificity of these antibodies. First, transient overexpression of $\mathrm{J} 3$ in Nicotiana benthamiana produced a specific $50-\mathrm{kDa}$ band that comigrated with the only protein detected in microsomal fractions of Arabidopsis lysates (Fig. 1D). Second, a transgenic line expressing a dexamethasone-inducible artificial miRNA targeting J3 (amiR-J3) in a $j 2$ knockout background (j2-2; SALK_071563) (Supplemental Fig. S1) showed reduced intensity of the $50-\mathrm{kDa}$ band specifically upon amiR-J3 induction (Fig. 1E). Thus, the 50-kDa band detected by the antibodies corresponds to $\mathrm{J} 2 / \mathrm{J} 3$ protein. We next used $N$. benthamiana to express His $_{6}-\mathrm{J}^{\mathrm{WT}}$ and $\mathrm{His}_{6}-\mathrm{J}^{\mathrm{C}}{ }^{\mathrm{C} 17 \mathrm{~S}}$ with a Cys-Ser mutation in the CaaX motif, precluding prenylation (Zhang and Casey 1996). Expression was carried out in the presence of the ${ }^{14} \mathrm{C}$-labeled prenyl precursor mevalonate to radioactively label prenylated proteins (Fig. 2A). Autoradiograms and Western blots of $\mathrm{Ni}^{2+}$ affinity-purified fractions separated by
SDS-PAGE showed clear incorporation of ${ }^{14} \mathrm{C}$ label into $\mathrm{His}_{6}-\mathrm{J} 3^{\mathrm{WT}}$ but not into $\mathrm{His}_{6}-\mathrm{J}^{\mathrm{C} 417 \mathrm{~S}}$, strongly suggesting that J3 is prenylated in vivo (Fig. 2B). Protein prenylation slightly increases protein migration rate in SDS-polyacrylamide gels (Kitten and Nigg 1991). We used this observation to further characterize 33 prenylation. A gel shift was visible between the transiently overexpressed $\mathrm{His}_{6}-\mathrm{J}^{\mathrm{WT}}$ and $\mathrm{His}_{6}-\mathrm{J}^{\mathrm{C} 417 \mathrm{~S}}$ proteins (Fig. $2 \mathrm{~B}$ ) and, more importantly, between N-terminally Flag-hemagglutinin (FHA)-tagged $\mathrm{J}^{\mathrm{WT}}$ and $3^{\mathrm{C}}{ }^{\mathrm{C} 17 \mathrm{~S}}$ immunopurified from stable transgenic lines (Fig. 2C). These data corroborate prenylation of $\mathrm{J} 3$ in vivo but do not distinguish between farnesylation and geranylgeranylation. To do so, we examined gel mobility of J2/J3 in microsome samples from Col0 wild type as well as farnesyl transferase (era1) and geranylgeranyl transferase $(g g b)$ mutants. J2/J3 migration was slower in samples prepared from the ERA1 deletion mutant era1-2 (Cutler et al. 1996) and from the T-DNA insertion mutant era1-9 (SAIL_146D09) but not from ggb-1 mutants (Fig. 2D; Johnson et al. 2005). Taken together, 


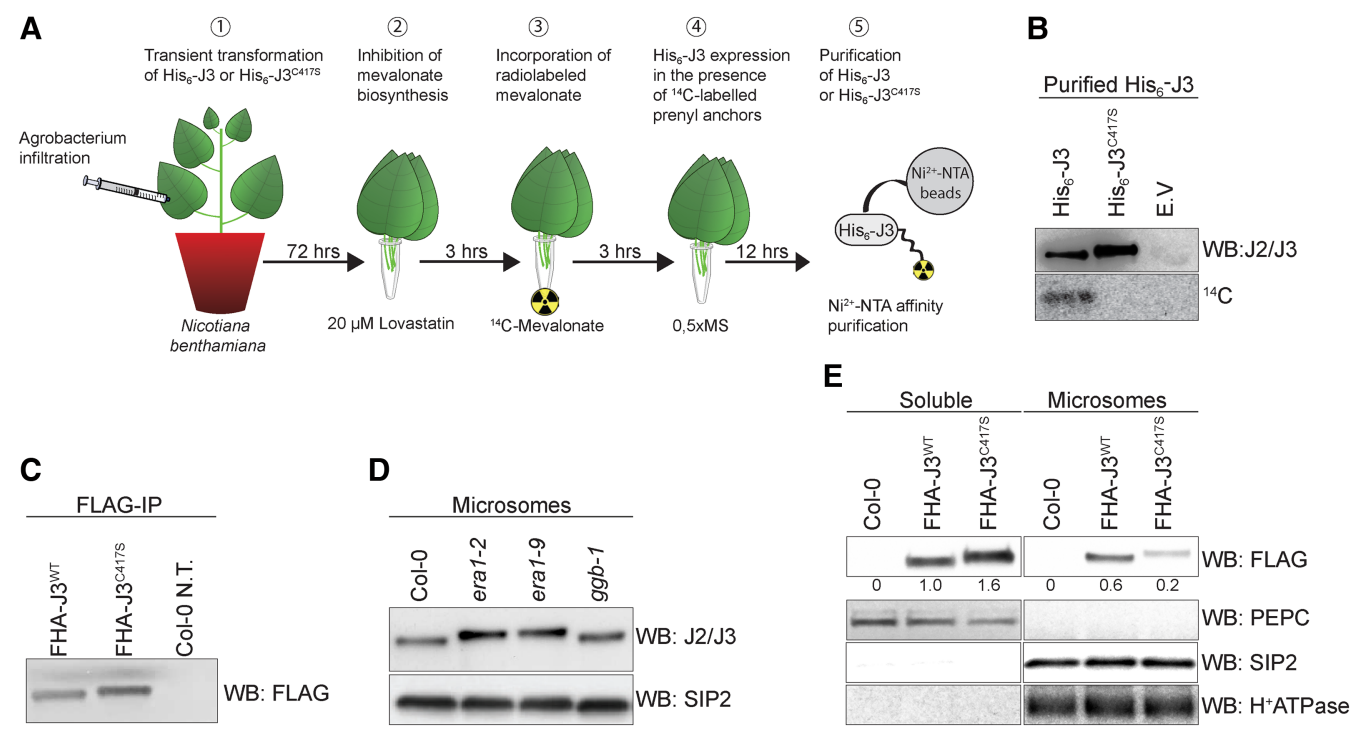

Figure 2. J3 is farnesylated in planta. (A) Schematic overview of transient expression of $\mathrm{His}_{6}$-J3 in N. benthamiana to test Cys417-dependent incorporation of the ${ }^{14} \mathrm{C}$-mevalonate-derived label into J3 protein. $(B) \mathrm{Ni}^{2+}$ affinity-purified fractions of extracts from $N$. benthamiana leaves transiently expressing $\mathrm{His}_{6}-\mathrm{J}_{3}, \mathrm{His}_{6}-\mathrm{J} 3{ }^{\mathrm{C} 417 \mathrm{~S}}$, or unfused His 6 (empty vector [E.V.]). (Top panel) Western blot analyzed with J2/J3-specific antibodies. (Bottom panel) Autoradiogram visualizing incorporated ${ }^{14} \mathrm{C}$ label. (C) Flag Western blot of Flag immunoprecipitates from inflorescences of Arabidopsis stable transgenic lines expressing FHA- $33^{\mathrm{WT}}$ or FHA- $\mathrm{J}^{\mathrm{C} 417 \mathrm{~S}}$. "Col-0 N.T." refers to Flag purification from inflorescences from the nontransgenic parental line (Col-0). (D) Western blot of microsome fractions from inflorescences probed with antibodies specific for J2/J3 and for the endoplasmic reticulum-localized small and basic intrinsic protein 2 (SIP2). Samples were separated extensively on $10 \%$ continuous polyacrylamide gels. $(E)$ Western blot analyses of soluble and microsome fractions from inflorescences of Arabidopsis stable transgenic lines expressing FHA- $3^{\mathrm{WT}}$ or FHA- $\mathrm{J}^{\mathrm{C} 417 \mathrm{~S}}$ and from the nontransgenic wild-type control (Col-0). Numbers below bands detected with Flag antibodies indicate intensity relative to the signal in the FHA-J $3^{\mathrm{WT}}$ soluble fraction lane. PEPC (phosphoenolpyruvate carboxylase) was used as a soluble protein control, and SIP2 and $\mathrm{H}^{+} /$ATPase were used as membrane-bound protein controls. Soluble and microsome fractions were loaded on the same gel, and the separation of panels is due to removal of the lane containing the size marker during figure mounting.

the gel mobility analyses and the incorporation of mevalonate-derived ${ }^{14} \mathrm{C}$ label into J $3^{\mathrm{WT}}$, but not into J3 ${ }^{\mathrm{C} 417 \mathrm{~S}}$, establish that $\mathrm{J} 3$ is farnesylated in vivo.

\section{I3 farnesylation facilitates its membrane association in vivo}

To determine whether J3 farnesylation is relevant for its membrane association, we analyzed soluble and microsomal fractions prepared from lysates of transgenic lines expressing FHA- $3^{\mathrm{WT}}$ and FHA- $3^{\mathrm{C} 417 \mathrm{~S}}$. The ratio between J3 quantity in soluble and membrane fractions was substantially higher in the farnesylation-defective FHA$\mathrm{J}^{\mathrm{C} 417 \mathrm{~S}}$ mutant than in FHA- $\mathrm{J} 3^{\mathrm{WT}}$ (Fig. 2E), indicating that farnesylation of $\mathrm{J} 3$ facilitates its membrane association.

\section{Farnesyl transferase interacts genetically with HSP9O}

If a lack of farnesylation of J2/J3 is important for phenotypes observed in farnesyl transferase mutants, genetic interactions between chaperone and farnesyl transferase mutants may be expected. We therefore tested the genetic interaction of era1-2 with the ATPase mutant hsp90.2-3 in one of five HSP90 isoforms. This mutant displays specific defects related to immune receptor activation but does not show developmental defects (Hubert et al.
2003). In contrast to either single mutant, era1-2/ hsp90.2-3 double mutants were completely sterile and showed defective flower and inflorescence morphology (Fig. 3A). This striking genetic interaction is conceptually similar to synthetic-lethal interactions in yeast. Genomewide mapping of such interactions shows that they tend to occur between ordered subsets of functionally linked genes (Costanzo et al. 2010). Therefore, although the strong genetic interaction between era1-2 and hsp90.2-3 in and of itself does not allow unambiguous conclusions on the relation between the two genes to be drawn, it does suggest the existence of functionally important links between protein farnesylation and the HSP90 pathway. Consistent with this interpretation, we observed dramatically increased levels of J2/J3, HSP70, and HSP90 in farnesyl transferase mutants compared with wild type (Fig. 3B). These observations reinforce the hypothesis that the molecular basis of farnesyl transferase mutant phenotypes may involve chaperone farnesylation.

\section{Mutants defective in T2/J3 farnesylation exhibit ABA hypersensitivity and drought resistance similar to era 1}

To test the possible importance of J2/J3 farnesylation directly, we first attempted to generate double-knockout mutants in 72 and $J 3$ and used the T-DNA insertion alleles 
A

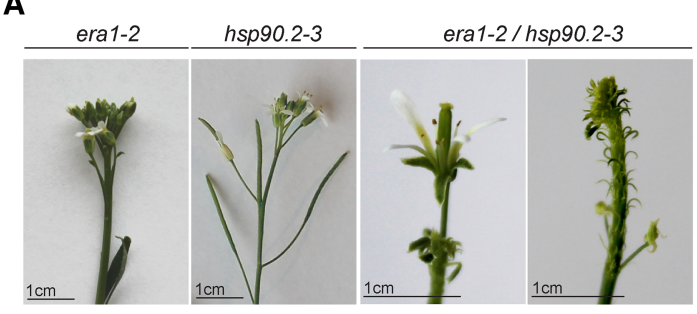

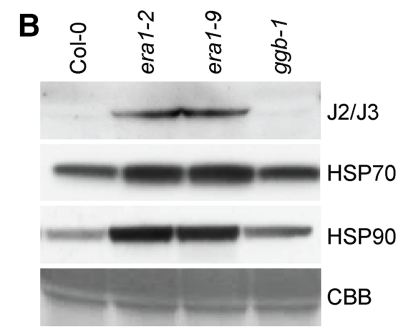

Figure 3. Genetic evidence for functional links between ERA1 and HSP40/70/90. (A) Inflorescences of era1-2, hsp90.2-3, and era1-2/hsp90.2-3 mutants. (B) Accumulation of J2/J3, HSP70, and HSP90 protein measured by Western blotting of total protein extracts from inflorescences. (CBB) Coomassie brilliant blue staining of the membrane used for antibody incubations. j2-2 and j3-2 (SALK_141625). The previously uncharacterized allele j3-2 contains a T-DNA insertion close to the one in j3-1 and showed similar loss of J3 mRNA (Supplemental Fig. S1). No double mutants could be identified in the progeny of $j 2-2 / j 2-2 ; j 3-2 /+$ parents, and reciprocal crosses of $j 2-2 / j 2-2 ; j 3-2 /+$ to wild type showed that simultaneous transmission of j2-2 and j3-2 knockout alleles through the pollen occurred with dramatically reduced frequency (Supplemental Table S1). However, it was possible to construct transgenic lines expressing either $\mathrm{J}^{\mathrm{WT}}$ or the farnesylation-defective $\mathrm{J}^{\mathrm{C} 417 \mathrm{~S}}$ in the $j 2-2 / j 3-2$ double knockout, indicating that not all J2/J3 activities depend fully on their farnesylation. Similar lines were also constructed in a $j 3$ single-mutant background. We first tested the sensitivity to ABA in a germination assay.
Remarkably, transgenic lines expressing $3^{\mathrm{C} 417 \mathrm{~S}}$ in $j 2-2 / j 3$ 2 exhibited pronounced ABA hypersensitivity, similar to era1-2 mutants (Fig. 4A). This phenotype required simultaneous loss of farnesylation of $\mathrm{J} 2$ and $\mathrm{J} 3$ because neither j3-1 single-knockout mutants nor j3-1 expressing J3 ${ }^{\mathrm{C} 417 \mathrm{~S}}$ exhibited the same strong ABA hypersensitivity (Supplemental Fig. S2). We next tested the drought resistance of mature rosettes. $j 2-2 / j 3-2$ expressing $\mathrm{J}^{\mathrm{C} 417 \mathrm{~S}}$ exhibited water retention similar to era1 mutants (Fig. 4B), significantly above the level observed in wild type. Consistent with this result, when plants were rehydrated after prolonged drought, survivors were found only among era1-2 mutants and the transgenic $12-2 / j 3-2$ line expressing $\mathrm{J3}^{\mathrm{C} 417 \mathrm{~S}}$ (Fig. 4C). These analyses show that lack of farnesylation of $\mathrm{J} 2$ and $\mathrm{J} 3$ is sufficient to confer $\mathrm{ABA}$
A

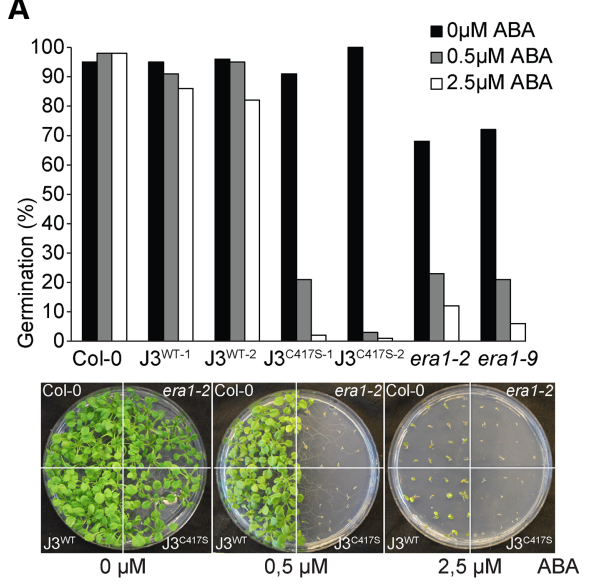

B

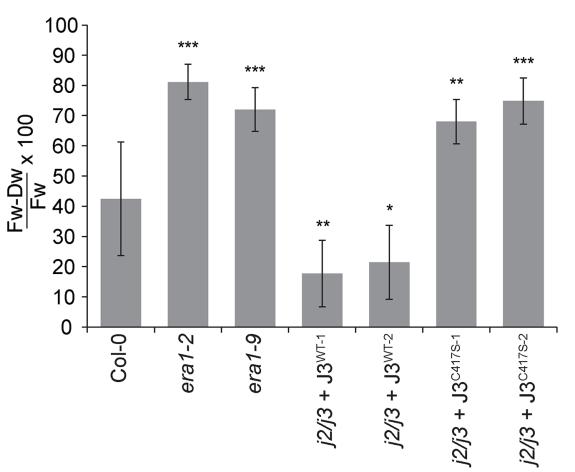

C

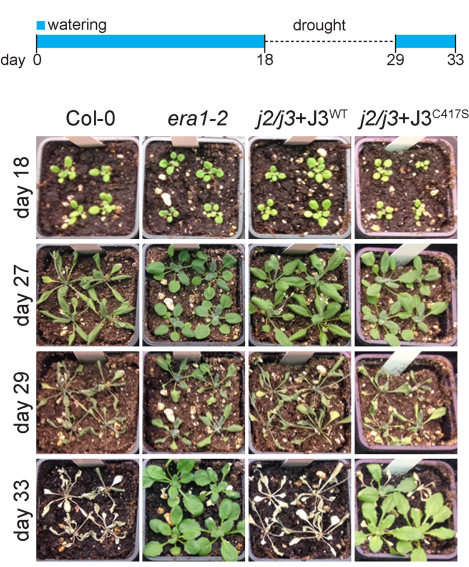

D

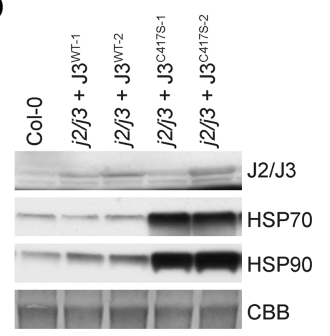

Figure 4. J2/J3 are key farnesylated targets for ABA signaling and drought resistance. $(A, t o p)$ Germination rate measured as fraction of seeds with emerging radicals from seed coats $48 \mathrm{~h}$ after transfer to $21^{\circ} \mathrm{C} /$ light growth conditions. $n=100$. (Bottom) Pictures of plates after $14 \mathrm{~d}$ of growth on plates with the indicated concentrations of ABA. The experiment was repeated twice with independent seed lots. Seed lots originated from parental plants that were grown side by side, and mutant and wild-type seeds were cleaned at the same time and stored together before use in the experiments. Two independent lines of $\mathrm{J}^{\mathrm{WT}}$ and $\mathrm{J3}^{\mathrm{C} 417 \mathrm{~S}}$ in the $j 2-2 / j 3-2$ background were analyzed $\left(\mathrm{J} 3^{\mathrm{WT}-1}, \mathrm{~J} 3^{\mathrm{WT}-2}, \mathrm{~J} 3^{\mathrm{C} 417 \mathrm{~S}-1}\right.$, and $\left.\mathrm{J} 3^{\mathrm{C} 417 \mathrm{~S}-2}\right) \cdot(B)$ Water retention in 5-wk-old rosettes after a 2 -wk period without watering. Asterisks indicate mean values that differ significantly from those obtained in Col-0 wild type. $\left.{ }^{(* *}\right) P<0.001 ;\left({ }^{* *}\right) P<0.01 ;\left({ }^{*}\right) P<0.05$, twotailed $t$-test, equal variance. The results obtained in era1-2, era1-9, and the two independent $\mathrm{J} 3^{\mathrm{C} 417 \mathrm{~S}}$ lines are not significantly different. $n=10 .(C)$ Survival of plants of the indicated genotypes $2 \mathrm{~d}$ after rehydration following a 12-d drought treatment. Under these conditions, Col-0 or $j 2-2 / j 3-2+3^{\mathrm{WT}}$ survivors were never identified, while most, but not all, era1-2 and $j 2-2 / j 3-2$ $+\mathrm{J} 3^{\mathrm{C} 417 \mathrm{~S}}$ plants survived. $(D)$ Accumulation of $\mathrm{J} 2 / \mathrm{J} 3$, HSP70, and HSP90 protein measured by Western blotting of total protein extracts from inflorescences. The same transgenic lines as those analyzed in $A$ and $C$ were used. (CBB) Coomassie brilliant blue staining of the membrane used for antibody incubations. 
hypersensitivity and drought resistance similar to what is observed in farnesyl transferase mutants. At the molecular level, we observed strong up-regulation of HSP70 and HSP90 in j2-2/j3-2 expressing J3 ${ }^{\mathrm{C} 417 \mathrm{~S}}$ (Fig. 4D), indicating that defective $\mathrm{J} 2 / \mathrm{J} 3$ farnesylation is the cause of their induction in farnesyl transferase mutants. Despite the use of the endogenous $\mathrm{J} 3$ promoter, J3 protein was also overexpressed in these transgenic lines regardless of the presence of the Cys417Ser mutation (Fig. 4D). Some chaperone clients are stabilized upon chaperone binding, including the TIR1 class of auxin receptors (Wang et al. 2016). Since ABA receptors, similar to the TIR1 family, contain hydrophobic binding sites (Nishimura et al. 2009) and therefore are potential HSP40-HSP70-HSP90 clients, we tested steady-state levels of both classes of protein in farnesyl transferase mutants. While TIR 1 protein indeed substantially overaccumulated in era1, plp, and $j 2 / j 3+\mathrm{J3}^{\mathrm{C} 417 \mathrm{~S}} \mathrm{mu}-$ tants, no clear effect on accumulation of the $\mathrm{ABA}$ receptor PYR1 could be detected (Supplemental Fig. S3). We also could not detect consistent SnRK2 hyperactivation in response to $\mathrm{ABA}$ in era1 compared with wild type, as would be expected if ABA receptor activity were increased as a consequence of chaperone overaccumulation (Supplemental Fig. S4). Thus, while J2/J3 are clearly key farnesylation targets, the precise point at which they act in ABA signaling remains unclear.

\section{Farnesylation-deficient 33 mutants have enlarged meristems and developmental phenotypes similar to era1 mutants}

era1 mutants exhibit developmental phenotypes, including late flowering, altered phyllotaxis, reduced fertility, and a stochastic increase in petal number (Running et al. 1998; Yalovsky et al. 2000; Ziegelhoffer et al. 2000). The underlying cause of some of these phenotypes may relate to the defective control of meristem size. Both era 1 and $p l p$ exhibit enlarged meristems, suggesting that farnesylated targets somehow control the balance between cellular proliferation and differentiation in the meristem (Running et al. 1998; Yalovsky et al. 2000). Remarkably, all of these phenotypes were apparent in j2-2/ j3-2 lines expressing J3 ${ }^{\mathrm{C} 417 \mathrm{~S}}$, although the stochastic increase in petal number was less penetrant than in era1-2 (Fig. 5A-C; Supplemental Fig. S5). We conclude that J2/ $\mathrm{J} 3$ are particularly important farnesylation targets for several previously described developmental phenotypes of farnesyl transferase mutants, including defective control of meristem size.

\section{Farnesyl transferase and farnesylation-deficient 13 mutants fail to express miRNAs controlled by SPL 7}

miRNAs control many aspects of plant development and stress responses, and mutants in miRNA biogenesis factors exhibit ABA hypersensitivity similar to era1 mutants (Lu and Fedoroff 2000; Hugouvieux et al. 2001; Han et al. 2004; Laubinger et al. 2008; Zhang et al. 2008). To test whether defects in miRNA production were discernible in farnesyl transferase and j2-2/j3-2 mutants expressing $\mathrm{J3}^{\mathrm{C} 417 \mathrm{~S}}$, we used small RNA sequencing (sRNA-seq) to profile small RNA populations in Col-0, era1-2, and the transgenic lines $j 2-2 / j 3-2+3^{\mathrm{WT}}$ and $j 2-2 / j 3-2+\mathrm{J} 3^{\mathrm{C} 417 \mathrm{~S}}$. The results showed that while most miRNAs accumulated normally in era1 and $j 2-2 / j 3-2+3^{\mathrm{C} 417 \mathrm{~S}}$, a small group of abiotic stress- and copper-responsive miRNAs (miR397)
A

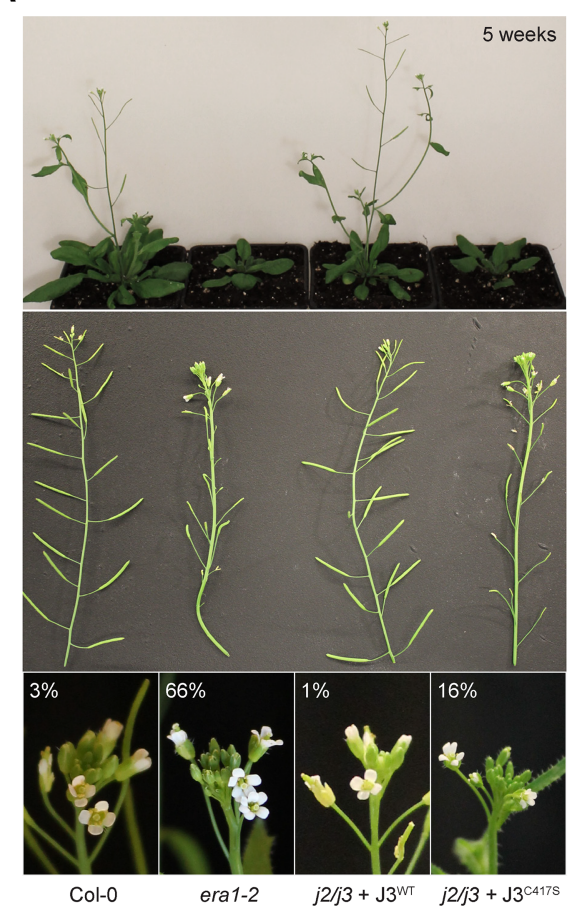

B

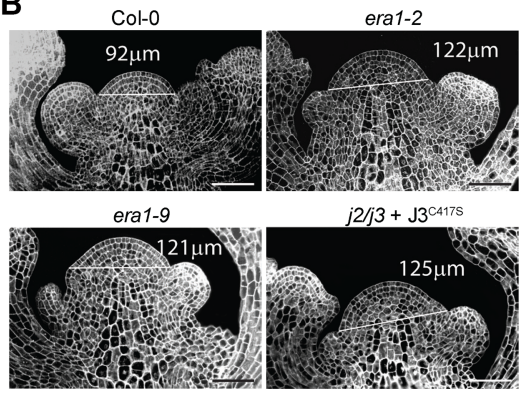

C

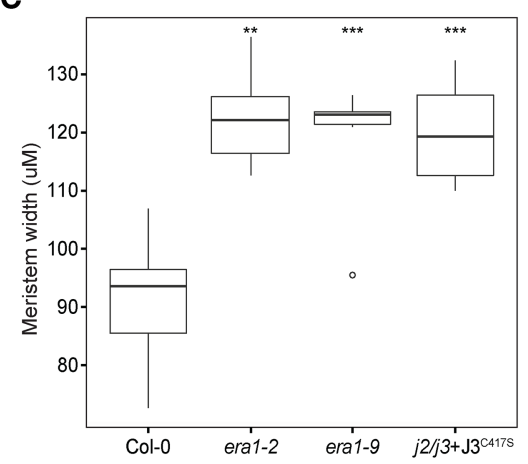

Figure 5. J2/J3 are key farnesylation targets in plant development. (A) Delayed flowering and inflorescence phenotypes of era1-2 and $j 2 / j 3$ expressing $\mathrm{J}^{\mathrm{C} 417 \mathrm{~S}}$. Under the growth conditions used, little, if any, individual variation was observed such that, in a given period of time, all Col-0 and $\mathrm{J} 3^{\mathrm{WT}}$ individuals had bolted, while no era12 and $3^{\mathrm{C} 417 \mathrm{~S}}$ had done so. Numbers in the bottom panel indicate the frequency of flowers with supernumerary petals (more than four). $n=100 .(B)$ Representative micrographs of inflorescence meristems from the indicated genotypes. The width of the meristem was measured as the length of the white line originating at the youngest primordium. Bar, $50 \mu \mathrm{m}$. A separate set of plants was used for side-by-side comparison of $j 2-3 / j 3-2+3^{\mathrm{WT}}$ and $j 2-3 / j 3-2+\mathrm{J} 3^{\mathrm{C} 417 \mathrm{~S}}$ (Supplemental Fig. S5). (C) Box plot depicting the measured width of inflorescence meristems in the indicated genotypes. Asterisks indicate mean values significantly different from Col-0. $\left(^{* * *}\right) P<0.001$, two-tailed $t$-test, equal variance. $n=7$. 
$398 / 408 / 857)$ showed markedly reduced accumulation in both era1-2 and $j 2-2 / j 3-2+3^{\mathrm{C} 417 \mathrm{~S}}$ (Fig. 6A). Indeed, miRNA expression profiles of era1-2 and $j 2-2 / j 3-2+\mathrm{J}^{\mathrm{C} 417 \mathrm{~S}}$ were nearly identical (Fig. 6A). Northern blots confirmed that miR398 and miR408 levels were strongly reduced in farnesyl transferase mutants, including $p l p$ and independent alleles of era1, and in farnesylation-defective $\mathrm{J}^{\mathrm{C} 417 \mathrm{~S}}$ lines (Fig. 6B). miR398 accumulation was also weakly affected in j3-2 single, but not in j2-2, mutants (Supplemental Fig. S6). miR397/398/408/857 are all controlled by the transcription factor SPL7 (Yamasaki et al. 2009), suggesting that their transcription may be compromised upon loss of HSP40 farnesylation. Indeed, pri-miR397a, pri$\mathrm{miR} 398 \mathrm{~b} / \mathrm{c}$, and pri-miR857 levels were strongly reduced in farnesyl transferase mutants and in farnesylation-defective $\mathrm{J}^{\mathrm{C} 417 \mathrm{~S}}$ lines (Fig. 6C), in contrast to other pri-miRNAs that showed levels similar to wild type (Fig. 6D). Remarkably, pri-miR398a, encoded by the only MIR398 gene whose transcription is not controlled by SPL7 (Yamasaki et al. 2009), accumulated to higher levels in era1-2 and in farnesylation-defective $\mathrm{J}^{\mathrm{C} 417 \mathrm{~S}}$ lines than in wild type (Fig. 6E). This observation further supports defective SPL7 function as the cause of reduced miR397-398-408857 accumulation upon loss of $\mathrm{J} 2 / \mathrm{J} 3$ farnesylation and may provide an explanation for residual miR398 levels detected in farnesyl transferase and farnesylation-defective $\mathrm{J} 3^{\mathrm{C} 417 \mathrm{~S}}$ lines.

\section{Activation of SPL7 requires farnesylated HSP4O}

SPL7 is produced as an ER membrane-bound preprotein whose activation by low copper levels involves proteolytic cleavage and translocation of the soluble product to the nucleus (Garcia-Molina et al. 2014). We therefore asked whether the pathway directing SPL7 activation was compromised upon loss of HSP40 farnesylation-a scenario that would be consistent with our observation that HSP40 farnesylation enhances membrane association (Fig. 2E). We first tested induction by low copper availability of a series of known direct SPL7 target genes (Yamasaki et al. 2009; Bernal et al. 2012; Garcia-Molina et al. 2014) and used an SPL7 T-DNA insertion mutant (sp17-3; SALK_125385) as a control for SPL7 dependence of induction. All of the target genes tested showed compromised, but not fully abrogated, induction in era1-2 and $j 2-2 / j 3-2$ $+3^{C 417 S}$, while SPL7 mRNA itself was normally expressed (Fig. 7A). We next used the observation that constitutive expression of a fragment of SPL7 containing only the soluble part homologous to other transcription factors in the SPL family (SPL $7{ }^{\mathrm{SBP}}$ ) is sufficient to induce SPL7 target genes in young seedlings in the presence of copper (Garcia-Molina et al. 2014). We generated stable transgenic lines expressing YFP:SPL $7^{\mathrm{SBP}}$ in wild type, era1-2, and spl7-3 genetic backgrounds and tested growth phenotypes and expression of SPL7-dependent miRNAs in pools of primary transformants. Expression of YFP: SPL $7{ }^{\text {SBP }}$ complemented growth defects of sp17-3 (Fig. 7B), indicating that it retained SPL7 function. YFP: SPL $7^{\mathrm{SBP}}$ was not fully functional, however, because despite expression of the YFP-SPL $7^{\text {SBP }}$ mRNA /Supplemen- tal Fig. S7), only partial restoration of miR398 was observed in sp17-3 (Fig. 7C). Importantly, expression of YFP:SPL $7^{\text {SBP }}$ in era1-2 fully restored the levels of mature miR398, while a more modest twofold increase was observed for miR408 (Fig. 7C). Taken together, the defective mRNA expression of direct SPL7 targets, but not SPL7, in era1-2 and $j 2-2 / j 3-2+/ 3^{C 417 S}$ and the partial restoration of miR398/miR408 expression by YFP:SPL $7^{\text {SBP }}$ indicate that a functional pathway for SPL7 activation requires farnesylation of HSP40.

\section{Discussion}

The importance of HSP4O farnesylation and its relation to other farnesyl transferase targets implicated in ABA-related phenotypes

Our study demonstrates that the requirement for farnesylation of the HSP40 chaperones J2/J3 underlies the previously described phenotypes of farnesyl transferase mutants related to meristem size, ABA responses, and drought resistance. Two obvious questions arise in the wake of this discovery: First, could other HSP40 proteins in the $>100$-member J domain family be implicated in explaining farnesyl transferase mutant phenotypes? Knockout of $J 1$, a distantly related and nonfarnesylated paralog of $\mathrm{J} 2 / \mathrm{J} 3$, does in fact lead to increased ABA hypersensitivity and drought resistance, but developmental phenotypes of $j 1$ mutants are different from those of era1 (Park and Kim 2014). It is possible that perturbation of several different HSP40 proteins, including J1 and J2/J3, leads to HSP70/HSP90 induction and that this is the cause of ABA hypersensitivity and drought resistance. The observation that overexpression of HSC70-1 is sufficient to cause ABA-hypersensitive seed germination (Clement et al. 2011) is consistent with this model. Second, which, if any, other farnesylated proteins play roles in farnesyl transferase mutant phenotypes? Two recent studies have yielded results on proteins whose lack of farnesylation may contribute to ABA- and drought-related phenotypes of farnesyl transferase mutants. In the first, the WD40 repeat protein ALTERED SEED GERMINATION2 (ASG2) was shown to be farnesylated, and asg2 knockout mutants exhibit ABA-hypersensitive inhibition of germination (Bassel et al. 2011; Dutilleul et al. 2016). asg2 mutants did not exhibit drought resistance at the rosette level, however, and asg2 point mutants in the farnesylation site were not examined in the seed germination assay (Dutilleul et al. 2016), precluding the drawing of clear conclusions on the relevance of ASG2 farnesylation. In the second study, a screen of CaaX motif proteins regulated by $\mathrm{ABA}$ led to the identification of the cytochrome P450 enzyme CYP85A2, implicated in brassinosteroid biosynthesis (Northey et al. 2016). A CYP85A2 CaaX motif mutant showed mild ABA-hypersensitive inhibition of germination and drought resistance of rosettes (Northey et al. 2016), although the ABA-hypersensitive germination was substantially less pronounced than in era1 and what we observed here for farnesylation-deficient $j 2-2 / j 3-2+J 3^{C 417 S}$ lines. One 
A
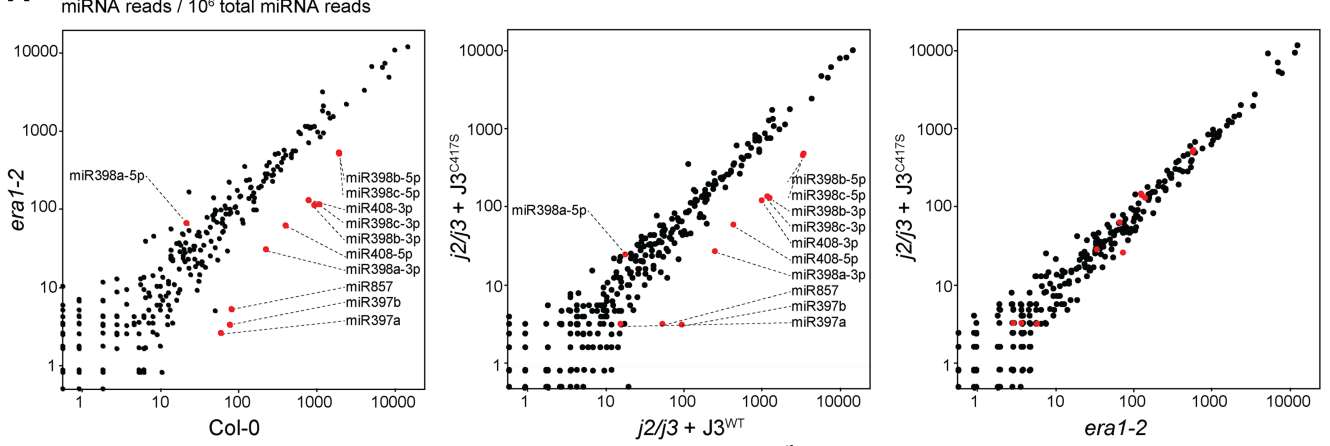

B
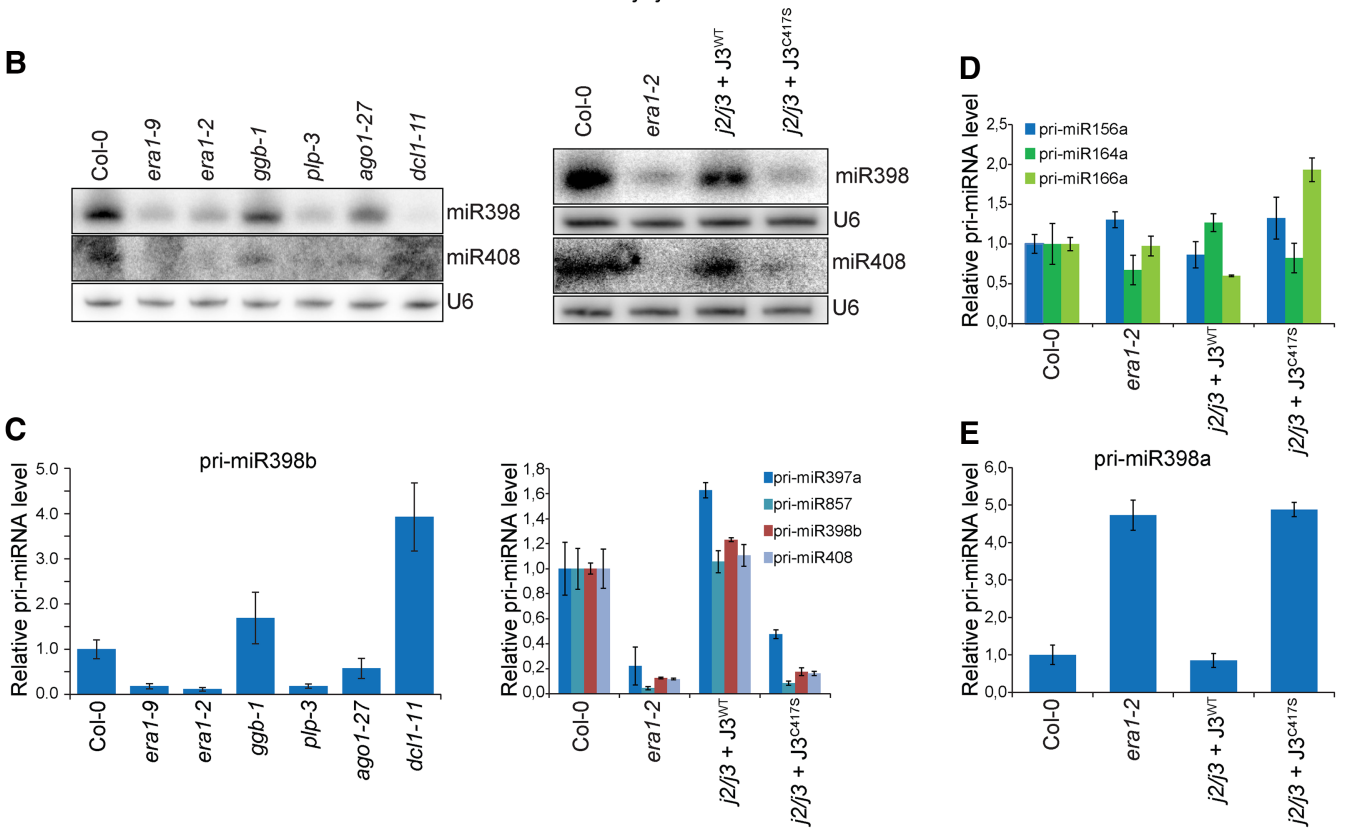

Figure 6. Expression of miR397/398/408/857 is impaired in the absence of J2/J3 farnesylation. (A) Plots of read counts of miRbasematching small RNAs. (Left panel) Col-0 (abscissa) versus era1-2. (Middle panel) j2-2/j3-2 expressing J3 ${ }^{\mathrm{WT}}$ (abscissa) versus J3 ${ }^{\mathrm{C} 417 \mathrm{~S}}$. (Right panel) era1-2 (abscissa) versus $j 2-2 / j 3-2$ expressing J3 ${ }^{\mathrm{C} 417 \mathrm{~S}}$. Two biological replicates of total RNA from pools of 16-d-old seedlings were used for preparation of libraries for sequencing. Seedlings of all genotypes used were grown together, and results are directly comparable. Dots colored in red show miRNAs in the miR397/398/408/857 group. (B) Northern blots of miR398 and miR408. Total RNA was extracted from 16-d-old seedlings of the indicated genotypes. Mutants in the miRNA effector AGO1 (ago1-27) and in the requisite miRNA biogenesis factor DCL1 (dcl1-11) were included as controls. The plp-3 mutant is a previously uncharacterized exonic T-DNA insertion in the PLP gene (GABI-KAT_386_C07) (Supplemental Fig. S1). The same Northern membrane was used for consecutive hybridization to miR398, miR408, and U6. (C) Quantitative RT-PCR analysis of pri-miR397a, pri-miR398b, pri-miR408, and pri-miR857 abundance. Sixteen-day-old sterile-grown seedlings were used for RNA extraction. For pri-miR397a, pri-miR398b, and pri-miR857, the same pool of oligo(dT)-primed cDNA was used as a template. For pri-miR408, gene-specific reverse transcription was performed to avoid amplification of an overlapping mRNA transcribed from the opposite strand. The figure shows results of one set of biological samples (50 seedlings pooled per RNA preparation) with standard deviation between technical triplicates, and the whole experiment was repeated twice with nearly identical results. (D) Quantitative RT-PCR analysis of pri-miR156a, pri-miR164a, and pri-miR166a mRNA abundance. The same RNA samples as those analyzed in $C$ were used. $(E)$ Quantitative RT-PCR analysis of pri-miR398a abundance, analyzed as described in $C$.

additional observation supports the notion that $\mathrm{J} 2 / \mathrm{J} 3$ are the main farnesylation targets to explain ABA hypersensitivity of farnesyl transferase mutants: The CYP85A2 farnesylation is not conserved in canola (Northey et al. 2016), in which ERA1 suppression leads to enhanced drought resistance (Wang et al. 2005, 2009). In contrast, the $\mathrm{J} 2 / \mathrm{J} 3$ farnesylation site is deeply conserved in plants and indeed in eukaryotes in general.

\section{Molecular functions of J2//3 farnesylation}

Our study shows that J3 farnesylation enhances its membrane association, consistent with a role as a membrane anchor. This may be important for some functions, including activation of SPL7 from its membrane-bound precursor. Studies on the yeast J3 ortholog Ydj1 suggest that the role of HSP40 farnesylation may not be limited to 


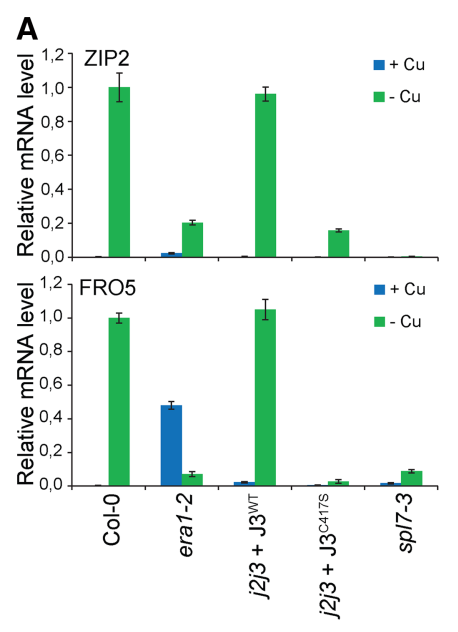

B

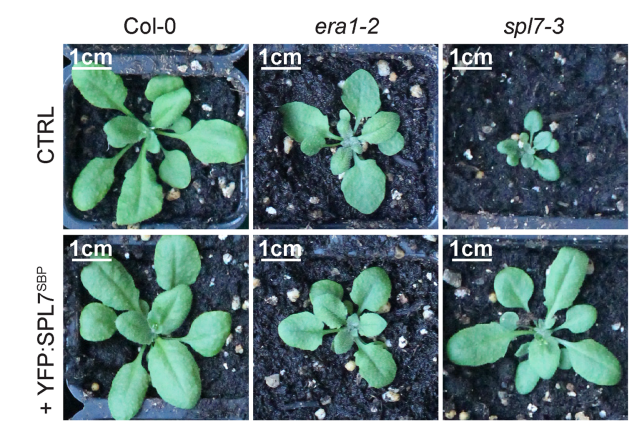

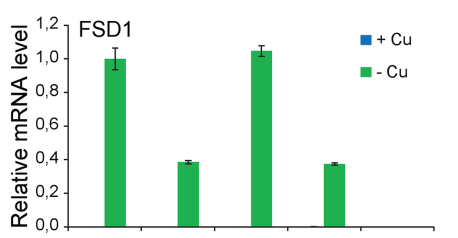
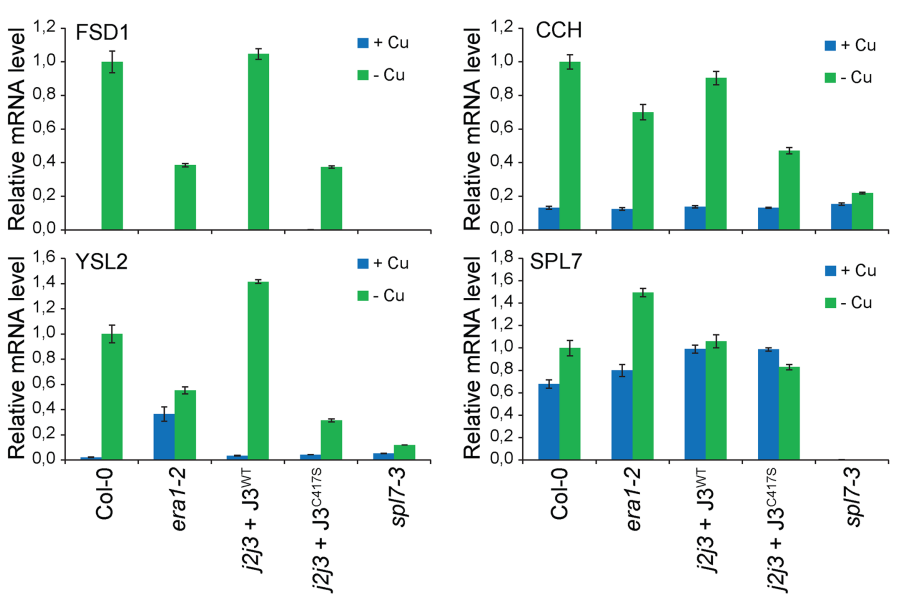

C

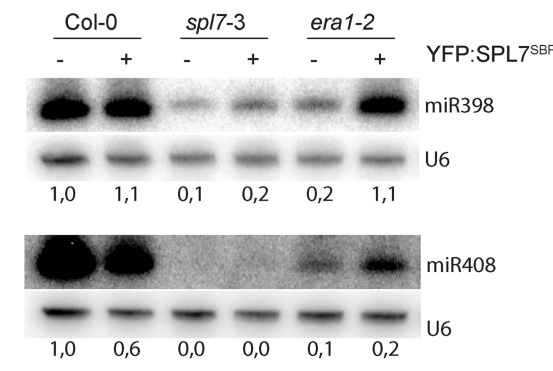

Figure 7. A functional SPL7 pathway requires J2/J3 farnesylation. (A) Quantitative RT-PCR analysis of CCH (AT3G56240), FSD1 (AT4G25100), FRO5 (AT5G23990), ZIP2 (AT5G59520), YSL2 (AT5G24380), and SPL7 mRNA abundance in 16-d-old seedlings grown on Murashige-Skoog medium either without $(-\mathrm{Cu})$ or supplemented with $(+\mathrm{Cu}) 5 \mu \mathrm{M} \mathrm{CuSO}$. The figure shows the results of one set of biological samples (50 seedlings pooled per RNA preparation) with standard error between technical triplicates. $(B)$ Four-week-old plants grown on soil of Col-0, era1-2, sp17-3 and representative primary transformants expressing the YFP:SPL $7^{\text {SBP }}$ transgene. $(C)$ RNA blot analysis of miR398 and miR408 abundance in leaves from pools of control plants and pools of five primary YFP:SPL $7^{\text {SBP }}$ transformants from each line.

membrane anchoring. First, the chaperone client Ste11 fails to bind to HSP90 in the absence of Ydj1 farnesylation (Flom et al. 2008), suggesting that chaperone-client interaction can involve farnesylation. Second, many farnesylation targets undergo cleavage of the CaaX site and carboxymethylation to enhance membrane anchor function (Wang and Casey 2016). Ydj1 does not undergo these additional modifications to enhance hydrophobicity and indeed loses function upon substitution with CaaX motifs that allow cleavage and carboxymethylation (Hildebrandt et al. 2016), suggesting that the role of farnesylation in the case of Ydj1 is not limited to membrane anchoring.

\section{A new framework for understanding the implication of protein farnesylation in plant biology}

It is a major conclusion of this study that a clear molecular understanding of farnesyl transferase mutant phenotypes requires identification of the relevant chaperone clients. We show here that a functional SPL7 pathway requires
$\mathrm{J} 2 / \mathrm{J} 3$ farnesylation, indicating that a component of this pathway, perhaps SPL7 itself, is a chaperone client. In addition, it is likely that the previously observed requirement for protein farnesylation for defense activation by $\mathrm{R}$ proteins (Goritschnig et al. 2008) is explained by defective HSP40/HSP70/HSP90 function because HSP70 and HSP90 are necessary for $\mathrm{R}$ protein function (Hubert et al. 2003; Takahashi et al. 2003; Noel et al. 2007). Candidates in $\mathrm{ABA}$ signaling include the $\mathrm{ABA}$ receptors that may use chaperones in vivo to maintain functional hydrophobic binding sites for ABA. We could not find evidence for such a model by measuring downstream SnRK2 kinase activity as a function of ABA concentration, but note that this approach is too crude to fully exclude the possibility that chaperones facilitate SnRK2 activation in vivo. We emphasize that two different effects on chaperone clients are likely to be at play upon loss of protein farnesylation. Some clients may lose function because they specifically interact with farnesylated J2/J3, while others may exhibit altered function because of induction of the HSP70HSP90 pathway. 


\section{Implication of miRNAs in enhanced drought tolerance of} farnesyl transferase mutants

The discovery that J2/J3 farnesylation is required for activation of the SPL7 pathway, including expression of $\mathrm{miR} 397 / \mathrm{miR} 398 / \mathrm{miR} 408 / \mathrm{miR} 857$, provides new insights into the possible molecular basis of drought resistance of farnesyl transferase mutants. Knockout of miR408 leads to increased drought resistance in Arabidopsis (Ma et al. 2015), and miR398 and/or miR408 are repressed in response to drought in many plant species, including rice, wheat, tomatoes, peas, and cotton (Zhou et al. 2010; Kantar et al. 2011; Wang et al. 2013; Jovanovic et al. 2014; Akdogan et al. 2016; Candar-Cakir et al. 2016). On the other hand, defective expression of these miRNAs is unlikely to cause developmental phenotypes of era1 because validated target mRNAs do not encode proteins known to control development (summarized in ArribasHernandez et al. 2016) and because spl7 mutants do not exhibit developmental phenotypes similar to era1 or $p l p$ (Yamasaki et al. 2009).

\section{Materials and Methods}

Plant growth conditions

Seeds were sterilized as described (Arribas-Hernandez et al. 2016) before being sown on Murashige-Skoog (MS) agar plates $(4.3 \mathrm{~g} / \mathrm{L}$ MS salts, $0.8 \%$ agar, $1 \%$ sucrose) or in soil containing $4 \%$ perlite and $4 \%$ vermiculite. For seedling analyses, plants were grown for $16 \mathrm{~d}$ on MS at a constant temperature $\left(21^{\circ} \mathrm{C}\right)$ and a 16 -h light (120 $\mu \mathrm{mol} \mathrm{m} \mathrm{m}^{-2} \mathrm{~s}^{-1} / / 8$-h darkness cycle. For analysis of adult leaves and inflorescences, plants were grown in growth chambers (Percival) with a 16-h photoperiod $\left(150 \mu \mathrm{mol} \mathrm{m} \mathrm{m}^{-2} \mathrm{~s}^{-1}\right), 21^{\circ} \mathrm{C} / 16^{\circ} \mathrm{C}$ daynight temperatures, and $70 \%$ relative humidity. For germination tests, seeds were incubated for $5 \mathrm{~d}$ at $4^{\circ} \mathrm{C}$ in darkness on MS plates containing $0,0.5$, or $2.5 \mu \mathrm{M}$ ABA. Germination frequencies of 100 seeds were counted after $48 \mathrm{~h}$ of incubation at $21^{\circ} \mathrm{C}$ with a $16-\mathrm{h}$ photoperiod. For dexamethasone induction of amiR-J3, seeds were germinated on MS medium containing $10 \mu \mathrm{M}$ dexamethasone. For tests of water retention in leaves, 3-wk-old rosettes were left unwatered in growth chambers for $14 \mathrm{~d}$, at which time leaf material was harvested, weighed (fresh weight), dried for 65 $\mathrm{h}$ at $60^{\circ} \mathrm{C}$, and reweighed (dry weight). For tests of survival upon drought, 16-d-old seedlings were left unwatered for $12 \mathrm{~d}$ and rehydrated, and survival was scored after an additional $2 \mathrm{~d}$. For analysis of YFP:SPL7-SBP primary transformants and respective controls, the leaves of five 4-wk-old plants were pooled before RNA extraction.

\section{DNA constructs}

Pro/3:J3:terJ3 and Pro/3:J3 ${ }^{\mathrm{C} 4175}$ :terJ3 constructs were made by a USER cloning strategy. PCR fragments containing 1333 base pairs (bp) of $J 3$ (AT3G44110) promoter and 482 bp downstream from the stop codon were amplified from BAC F26G5 with the primers $18 / 19$ and 20/21 for wild type and 18/19, 20/21, and 23/ 21 for C417S (Supplemental Table S2) and cloned into a derivative of pCAMBIA3300 containing a USER cassette (Nour-Eldin et al. 2006). ProJ3:2xFlag-2xHA-J3:ter/3 and Pro/3:2xFlag-2xHA$J 3^{C 4175}$ :ter/3 were constructed using primers $18 / 24,25 / 26$, and 27/21 (Supplemental Table S2). The 2xFlag-2-HA cassette was amplified from an SDE3-2xFlag-2xHA construct (Garcia et al. $2012)$, and $J 3$ and $\zeta^{C 417 S}$ fragments were amplified from the
Pro/3:J3:ter/3 and Pro/3:J3 ${ }^{C 4175}$ :ter/3 constructs described above. For construction of pEAQ-J3, a J3 cDNA was amplified from oligo(dT)-primed cDNA with primers 32/33 and cloned into the AgeI-XhoI site of pEAQ (Sainsbury et al. 2009). For construction of pEAQ-HT-J3 (His ${ }_{6}-\mathrm{J} 3$ ), a J3 cDNA was amplified with primers $28 / 29$, cloned into the entry vector pCR8/GW/TOPO (Invitrogen), and recombined into pEAQ-HT-dest2 (Sainsbury et al. 2009). To construct inducible amiR-J3, we designed an artificial miRNA sequence in the pri-miR319 backbone (Supplemental Table S2) using Web MicroRNA designer WMD3 (Ossowski et al. 2008). This DNA fragment, flanked by XhoI and SpeI restriction sites, was synthesized and cloned into the pSMART vector by Integrated DNA Technologies. The fragment containing the amiRNA sequence was then excised and ligated into pTA7002 (Aoyama and Chua 1997) using XhoI and SpeI sites. For construction of UBQ10:YFP-SPL7-SBP, SPL7-SBP from the plasmid pDONR-SPL7-SBP (Garcia-Molina et al. 2014) was recombined into pUBN-Dest(YFP) (Grefen et al. 2010). Sequences of all of the oligonucleotides used for cloning are in Supplemental Table S2, and a list of transgenic lines generated in this study is in Supplemental Table S3.

\section{Transformation of Arabidopsis}

Plants were transformed by floral dipping with Agrobacterium tumefaciens strain GV3101 (Clough and Bent 1998).

\section{Transient expression in N. benthamiana}

Expression plasmids were transformed into $A$. tumefaciens strain GV3101. Bacterial pellets from overnight cultures were resuspended in infiltration medium (10 mM MES, $10 \mathrm{mM} \mathrm{MgCl}_{2}$, $100 \mu \mathrm{M}$ acetosyringone at $\mathrm{pH} 5.6)$ at $\mathrm{OD}=0.6$ and infiltrated into $N$. benthamiana leaves with a $1-\mathrm{mL}$ syringe. Leaves were harvested after $72 \mathrm{~h}$ of expression. For ${ }^{14} \mathrm{C}$-mevalonate labeling experiments, infiltrated leaves were detached with the intact petiole $48 \mathrm{~h}$ after infiltration and immersed in $0.5 \times$ MS medium supplied with $20 \mu \mathrm{M}$ lovastatin to inhibit endogenous mevalonate biosynthesis. After $3 \mathrm{~h}$, the leaves were transferred to 2-mL tubes containing $500 \mu \mathrm{L}(50 \mu \mathrm{Ci}, 60 \mathrm{Ci} / \mathrm{mmol})$ of ${ }^{14} \mathrm{C}$-mevalonate and $500 \mu \mathrm{L}$ of $0.5 \times \mathrm{MS}$ until the entire volume had been taken up by the leaf. The leaves were then left in $0.5 \times$ MS for $12 \mathrm{~h}$. Total lysates were prepared, and $(\text { His })_{6}$-tagged protein was purified by immobilized $\mathrm{Ni}^{2+}$ affinity chromatography.

Mutant genotyping and double-mutant construction

Uncharacterized Arabidopsis T-DNA insertion mutants (era1-9, plp-3, j2-2, and j3-2) were genotyped using primers listed in Supplemental Table S2. The deletion in era1-2 was confirmed by PCR with primers inside the ERA1 gene body and by the total absence of signal in quantitative RT-PCRs from RNA prepared from era1-2 (Supplemental Table S2). era1-2/era1-2, hsp90.2-3/+ individuals were identified by PCR in F2 populations of era1-2 crossed to hsp90.2-3 using the absence of product with ERA1 gene body primers for era1-2 genotyping and primers 16 and 17 (Supplemental Table S2) followed by AseI digestion for hsp90.23 genotyping. Double-homozygous plants were identified in the F3 generation. $j 2-2 / j 3-2$ double mutants expressing $\mathrm{J} 3^{\mathrm{WT}}$ or $\mathrm{J}^{\mathrm{C} 417 \mathrm{~S}}$ transgenes were constructed as follows: $j 2-2 / j 2-2 ; j 3-2 /+$ was transformed by Pro/3: $/ 3^{W T}:$ ter $/ 3$ and Pro/3:J3 ${ }^{C 417 S}$ :terJ3 constructs. PCR screening of 200 primary transformants yielded no j2-2/j3-2 double homozygotes. T2 populations of 10 independent lines (five $J 3^{W T}$ and five $J 3^{C 417 S}$, all with $j 2-2 / j 2-2 ; j 3-2 /+$ genotypes) were then rescreened by PCR. Double homozygotes were 
identified in two independent lines for both $J 3^{W T}$ and $J 3^{C 417 S}$ constructs at the expected frequency of one in eight, taking into account that transgenic $/ 3$ must be transmitted through the pollen. Double-homozygous plants were amplified, and individuals homozygous for 33 transgenes were identified in subsequent generations before molecular and phenotypic analyses. A CAPS marker using PfeI digestion of amplified PCR products was developed to confirm the presence of $3^{C 417 S}$ (primers 14 and 15) (Supplemental Table S2). A list of mutants used and generated in the study is in Supplemental Table S3.

\section{Histological analysis of meristems}

Arabidopsis inflorescence meristems were isolated from the primary inflorescences of plants at the same developmental stage such that Col-0 plants were $\sim 8 \mathrm{~d}$ younger than farnesyl transferase and $\mathrm{J} 3$ mutant lines to compensate for the later flowering of the mutants. After $2 \mathrm{~h}$ of fixation in Karnovsky's fixative, material was dehydrated in a graded acetone series $130 \%, 50 \%, 70 \%$, $90 \%$, and $100 \%$ ). Samples where then infiltrated and embedded in Spurr's resin. Meristems were sectioned $(2 \mu \mathrm{m})$ on a SuperNova Reichert-Jung microtome, stained with $0.05 \%$ Toluidine blue-O (pH 4.4), and visualized in bright field using a Nikon Eclipse 80i fluorescence microscope. Measurements were performed using ImageJ software.

\section{RNA analyses}

Total RNA extraction and small RNA Northern blots were performed as described (Arribas-Hernandez et al. 2016). Sequences of oligonucleotide probes are in Supplemental Table S2. For quantitative RT-PCR, RNA was treated with DNase I (Fermentas) and converted to cDNA with Revert Aid reverse transcriptase (Fermentas) primed by oligo-(dT) according to the instructions. Quantitative PCR was performed with the SYBR Green master mix (Fermentas) on a CFX Connect real-time system (Bio-Rad). Melting curve analysis of products amplified by each primer pair showed that they amplified a single PCR product. Actin (ACT2) was used as a normalization control after verification of its robustness across the samples analyzed. The primers used are in Supplemental Table S2. Libraries for Illumina sequencing were prepared from $1 \mu \mathrm{g}$ of total seedling RNA using the NEBNext small RNA library preparation set (Multiplex, New England Biolabs). The quality of purified RNA and of constructed libraries was confirmed using an Agilent Bioanalyzer and sequenced on an Illumina platform (Aros).

Preparation of protein extracts and immunoblotting

Total seedling or inflorescence protein samples were prepared and analyzed by immunoblotting as described (Arribas-Hernandez et al. 2016).

\section{Affinity purification of $\mathrm{His}_{6}-\mathrm{J} 3$ and $\mathrm{FHA}-\mathrm{T} 3$}

His $_{6}-\mathrm{J} 3$ was purified by immobilized $\mathrm{Ni}^{2+}$ affinity chromatography using nitrilo triacetic acid (NTA)-conjugated agarose beads (Protino, Machery-Nagel) following the manufacturer's instructions. FHA-J3 was purified by immunoaffinity chromatography using M2-conjugated agarose beads (Sigma) following the manufacturer's instructions. For $\mathrm{Ni}^{2+}$-NTA purification, $5 \mathrm{~g}$ of $\mathrm{N}$. benthamiana leaf tissue was ground to a fine powder and lysed in 6 $\mathrm{mL}$ of lysis buffer $(50 \mathrm{mM}$ Tris $\mathrm{HCl}$ at $\mathrm{pH} 7.5,150 \mathrm{mM} \mathrm{NaCl}, 5$ $\mathrm{mM} \mathrm{MgCl} 2,0.1 \%$ nonidet $\mathrm{P} 40$, protease inhibitor cocktail Roche) and filtered through a $0.45-\mu \mathrm{m}$ acrodisc. A bed volume of $500 \mu \mathrm{L}$ of $\mathrm{Ni}^{2+}$-NTA agarose beads was used to bind $\mathrm{His}_{6}$-tagged proteins. Beads were collected on 15-mL disposable columns (Bio-Rad), and the flowthrough was reapplied once to the column. Columns were washed by 20 column volumes of wash buffer $(20 \mathrm{mM}$ Tris- $\mathrm{HCl}$ at $\mathrm{pH} 8,300 \mathrm{mM} \mathrm{NaCl}, 20 \mathrm{mM}$ imidazol, $1 \mathrm{mM}$ TCEP) and eluted in $500 \mu \mathrm{L}$ of elution buffer $(20 \mathrm{mM}$ Tris- $\mathrm{HCl}$ at $\mathrm{pH} 8,150 \mathrm{mM} \mathrm{NaCl}, 300 \mathrm{mM}$ imidazol, $1 \mathrm{mM}$ TCEP). A similar procedure was used for Flag immunoaffinity purification, except that $2 \mathrm{~g}$ of inflorescence tissue was used, and lysis, wash, and elution buffers had different compositions (lysis buffer: $50 \mathrm{mM}$ Tris $\mathrm{HCl}$ at $\mathrm{pH} 7.5,150 \mathrm{mM} \mathrm{NaCl}, 5 \mathrm{mM} \mathrm{MgCl}_{2}, 0.1 \%$ nonidet P40, protease inhibitor cocktail [Roche]; wash buffer: $50 \mathrm{mM}$ Tris $\mathrm{HCl}$ at $\mathrm{pH} 7.5,500 \mathrm{mM} \mathrm{NaCl}, 5 \mathrm{mM} \mathrm{MgCl}_{2}, 0.1 \%$ nonidet P40; elution buffer: $1 \times$ phosphate-buffered saline [PBS], $150 \mathrm{ng} /$ $\mu \mathrm{L}$ Flag peptide). A bed volume of $60 \mu \mathrm{L}$ of M2-agarose beads (Sigma) per milliliter of lysate was used.

\section{Antibodies}

Rabbit antibodies against HSP40 (J2/J3) were generated by Eurogentec (Belgium) using the following peptide as an antigen: $\mathrm{H}_{2} \mathrm{~N}$-CNHPDKGGDPEKFKEL-CONH${ }_{2}$. HSP70, HSP90, SIP2, $\mathrm{H}^{+}$/ATPase, and PYR1 antibodies were purchased from Agrisera, and PEPC (phosphoenolpyruvate carboxylase) antiserum was purchased from Rockland Immunochemicals. TIR1 antibodies were a kind gift from Lionel Navarro and were described in Arribas-Hernandez et al. (2016).

\section{Microsome fractionation}

Inflorescences were snap-frozen and ground to a fine powder, and $1.2 \mathrm{~mL}$ of microsome buffer (50 mM MOPS, 0.5 M sorbitol, 10 mM EDTA, 1\% BSA, Roche protease inhibitors version 11 [one tablet $/ 10 \mathrm{~mL}$ ] at $\mathrm{pH} 7.6$ ) was added to $0.2 \mathrm{~g}$ of ground tissue and vortexed thoroughly. Samples were spun at $8000 \mathrm{~g}$ for $10 \mathrm{~min}$ at $4^{\circ} \mathrm{C}$. Supernatants were transferred to new tubes and repeatedly spun at $8000 \mathrm{~g}$ until no pellet was visible. Supernatants ("total extracts") were spun at $100,000 \mathrm{~g}$ for $30 \mathrm{~min}$ at $4^{\circ} \mathrm{C}$. Pellets were resuspended in wash buffer (50 mM MOPS, 0.5 M sorbitol, $10 \mathrm{mM}$ EDTA, Roche protease inhibitors version 11 [one tablet $/ 10 \mathrm{~mL}$ ] at $\mathrm{pH}$ 7.6) and repelleted by centrifugation at $100,000 \mathrm{~g}$ for $30 \mathrm{~min}$ at $+4^{\circ} \mathrm{C}$. Pellets were resuspended in a small volume of $1 \times$ PBS buffer, and protein concentrations were measured using Bradford (Serva). Microsomes were solubilized in NuPAGE sample buffer (Invitrogen) or Laemmli sample buffer (Bio-Rad) before loading on SDS-PAGE gels.

\section{Analysis of small RNA-seq data}

Raw Illumina sequencing reads were preprocessed by trimming away the sequence of the miRNA ligation adapter (AGATCG GAAGAGCACACGTCTGAACTCC) using the program CutAdapt. Trimmed reads $<21$ nucleotides were discarded to be able to distinguish between mature miR398a and miR398b/c, which differ in sequence only at the 21 st nucleotide. The trimmed reads were aligned against sequences of the 427 Arabidopsis thaliana miRNAs annotated in miRBase version 21 using strand-specific alignment with Bowtie 2 (Langmead et al. 2009).

\section{Accession codes}

Small RNA-seq data have been deposited at the European Nucleotide Archive under ArrayExpress accession number EMTAB-3736. 


\section{Acknowledgments}

We thank the Nottingham Arabidopsis Stock Centre for seeds of T-DNA insertion lines, the Arabidopsis Biological Resource Center for BAC clones, Jeffery Dangl for hsp90.2-3 seeds, and Peter Huijser for the gift of the pDONR-SPL7-SBP plasmid. We thank Lars Østergaard, Sebastian Marquardt, Ignacio Rubio-Somoza, Laura Arribas-Hernández, and Simon Bressendorff for critical reading of the manuscript. This work was supported by a Hallas Møller Fellowship from the Novo Nordisk Foundation, a Starting Grant from the European Research Council (Micromecca, 282460), a block stipend from the Villum Foundation, and an instrument grant from the Augustinus Foundation (all to P.B.). A.B. and L.S. worked together on construction of $j 2-2 / j 3-2$ double-mutant lines expressing $\mathrm{J} 3$ transgenes, A.B. performed miRNA and SPL7 analyses, L.S. optimized conditions for use of the J2/J3 antibodies and performed fractionation and Western analyses, M.F. constructed FHA-J3 lines and His $_{6}-\mathrm{J} 3$ expression plasmids and performed the experiments with them, E.B.P. performed histological analyses, and A.B., L.S., M.F., E.B.P., S.W., and P.B. analyzed the data. P.B. designed the study and wrote the manuscript with input from all authors.

\section{References}

Akdogan G, Tufekci ED, Uranbey S, Unver T. 2016. miRNAbased drought regulation in wheat. Funct Integr Genomics 16: $221-233$.

Aoki Y, Okamura Y, Tadaka S, Kinoshita K, Obayashi T. 2016. ATTED-II in 2016: a plant coexpression database towards lineage-specific coexpression. Plant Cell Physiol 57: e5.

Aoyama T, Chua NH. 1997. A glucocorticoid-mediated transcriptional induction system in transgenic plants. Plant $J$ 11: 605-612.

Arribas-Hernandez L, Kielpinski LJ, Brodersen P. 2016. mRNA decay of most Arabidopsis miRNA targets requires slicer activity of AGO1. Plant Physiol 171: 2620-2632.

Bassel GW, Lan H, Glaab E, Gibbs DJ, Gerjets T, Krasnogor N, Bonner AJ, Holdsworth MJ, Provart NJ. 2011. Genome-wide network model capturing seed germination reveals coordinated regulation of plant cellular phase transitions. Proc Natl Acad Sci 108: 9709-9714.

Bernal M, Casero D, Singh V, Wilson GT, Grande A, Yang H, Dodani SC, Pellegrini M, Huijser P, Connolly EL, et al. 2012. Transcriptome sequencing identifies SPL7-regulated copper acquisition genes FRO4/FRO5 and the copper dependence of iron homeostasis in Arabidopsis. Plant Cell 24: 738-761.

Candar-Cakir B, Arican E, Zhang B. 2016. Small RNA and degradome deep sequencing reveals drought-and tissue-specific micrornas and their important roles in drought-sensitive and drought-tolerant tomato genotypes. Plant Biotechnol J 14: $1727-1746$.

Caplan AJ, Tsai J, Casey PJ, Douglas MG. 1992. Farnesylation of YDJ1p is required for function at elevated growth temperatures in Saccharomyces cerevisiae. I Biol Chem 267: 18890-18895.

Clement M, Leonhardt N, Droillard MJ, Reiter I, Montillet JL, Genty B, Lauriere C, Nussaume L, Noel LD. 2011. The cytosolic/nuclear HSC70 and HSP90 molecular chaperones are important for stomatal closure and modulate abscisic acid-dependent physiological responses in Arabidopsis. Plant Physiol 156: 1481-1492.
Clough SJ, Bent AF. 1998. Floral dip: a simplified method for Agrobacterium-mediated transformation of Arabidopsis thaliana. Plant J 16: 735-743.

Costanzo M, Baryshnikova A, Bellay J, Kim Y, Spear ED, Sevier CS, Ding H, Koh JL, Toufighi K, Mostafavi S, et al. 2010. The genetic landscape of a cell. Science 327: 425-431.

Cutler S, Ghassemian M, Bonetta D, Cooney S, McCourt P. 1996. A protein farnesyl transferase involved in abscisic acid signal transduction in Arabidopsis. Science 273: 1239-1241.

Cutler SR, Rodriguez PL, Finkelstein RR, Abrams SR. 2010. Abscisic acid: emergence of a core signaling network. Ann Rev Plant Biol 61: 651-679.

Dutilleul C, Ribeiro I, Blanc N, Nezames CD, Deng XW, Zglobicki P, Palacio Barrera AM, Atehortua L, Courtois M, Labas $\mathrm{V}$, et al. 2016. ASG2 is a farnesylated DWD protein that acts as ABA negative regulator in Arabidopsis. Plant Cell Environ 39: 185-198.

Elkayam E, Kuhn CD, Tocilj A, Haase AD, Greene EM, Hannon GJ, Joshua-Tor L. 2012. The structure of human argonaute-2 in complex with miR-20a. Cell 150: 100-110.

Flom GA, Lemieszek M, Fortunato EA, Johnson JL. 2008. Farnesylation of Ydj1 is required for in vivo interaction with Hsp90 client proteins. Mol Biol Cell 19: 5249-5258.

Fu HW, Casey PJ. 1999. Enzymology and biology of CaaX protein prenylation. Rec Progr Horm Res 54: 315-342.

Fujii H, Zhu JK. 2009. Arabidopsis mutant deficient in 3 abscisic acid-activated protein kinases reveals critical roles in growth, reproduction, and stress. Proc Natl Acad Sci 106: 8380-8385.

Fujita Y, Nakashima K, Yoshida T, Katagiri T, Kidokoro S, Kanamori N, Umezawa T, Fujita M, Maruyama K, Ishiyama K, et al. 2009. Three SnRK2 protein kinases are the main positive regulators of abscisic acid signaling in response to water stress in Arabidopsis. Plant Cell Physiol 50: 2123-2132.

Furihata T, Maruyama K, Fujita Y, Umezawa T, Yoshida R, Shinozaki K, Yamaguchi-Shinozaki K. 2006. Abscisic acid-dependent multisite phosphorylation regulates the activity of a transcription activator AREB1. Proc Natl Acad Sci 103: 1988-1993.

Garcia D, Garcia S, Pontier D, Marchais A, Renou JP, Lagrange T, Voinnet O. 2012. Ago hook and RNA helicase motifs underpin dual roles for SDE3 in antiviral defense and silencing of nonconserved intergenic regions. Mol Cell 48: 109-120.

Garcia-Molina A, Xing S, Huijser P. 2014. Functional characterisation of Arabidopsis SPL7 conserved protein domains suggests novel regulatory mechanisms in the $\mathrm{Cu}$ deficiency response. BMC Plant Biol 14: 231.

Geiger D, Scherzer S, Mumm P, Stange A, Marten I, Bauer H, Ache P, Matschi S, Liese A, Al-Rasheid KA, et al. 2009. Activity of guard cell anion channel SLAC1 is controlled by drought-stress signaling kinase-phosphatase pair. Proc Nat1 Acad Sci 106: 21425-21430.

Goritschnig S, Weihmann T, Zhang Y, Fobert P, McCourt P, Li X. 2008. A novel role for protein farnesylation in plant innate immunity. Plant Physiol 148: 348-357.

Grefen C, Donald N, Hashimoto K, Kudla J, Schumacher K, Blatt MR. 2010. A ubiquitin-10 promoter-based vector set for fluorescent protein tagging facilitates temporal stability and native protein distribution in transient and stable expression studies. Plant J 64: 355-365.

Han MH, Goud S, Song L, Fedoroff N. 2004. The Arabidopsis double-stranded RNA-binding protein HYL1 plays a role in microRNA-mediated gene regulation. Proc Natl Acad Sci 101: 1093-1098. 
Hernandez MP, Chadli A, Toft DO. 2002a. HSP40 binding is the first step in the HSP90 chaperoning pathway for the progesterone receptor. J Biol Chem 277: 11873-11881.

Hernandez MP, Sullivan WP, Toft DO. 2002b. The assembly and intermolecular properties of the hsp70-Hop-hsp90 molecular chaperone complex. J Biol Chem 277: 38294-38304.

Hildebrandt ER, Cheng M, Zhao P, Kim JH, Wells L, Schmidt WK. 2016. A shunt pathway limits the CaaX processing of Hsp40 Ydj1p and regulates Ydjlp-dependent phenotypes. Elife 5: e15899.

Hubert DA, Tornero P, Belkhadir Y, Krishna P, Takahashi A, Shirasu K, Dangl JL. 2003. Cytosolic HSP90 associates with and modulates the Arabidopsis RPM1 disease resistance protein. EMBO I 22: 5679-5689.

Hugouvieux V, Kwak JM, Schroeder JI. 2001. An mRNA cap binding protein, $\mathrm{ABH1}$, modulates early abscisic acid signal transduction in Arabidopsis. Cell 106: 477-487.

Iki T, Yoshikawa M, Nishikiori M, Jaudal MC, MatsumotoYokoyama E, Mitsuhara I, Meshi T, Ishikawa M. 2010. In vitro assembly of plant RNA-induced silencing complexes facilitated by molecular chaperone HSP90. Mol Cell 39: 282-291.

Jalakas P, Huang YC, Yeh YH, Zimmerli L, Merilo E, Kollist H, Brosche M. 2017. The role of ENHANCED RESPONSES TO ABA1 (ERA1) in Arabidopsis stomatal responses is beyond ABA signaling. Plant Physiol 174: 665-671.

Johnson BD, Schumacher RJ, Ross ED, Toft DO. 1998. Hop modulates Hsp70/Hsp90 interactions in protein folding. I Biol Chem 273: 3679-3686.

Johnson CD, Chary SN, Chernoff EA, Zeng Q, Running MP, Crowell DN. 2005. Protein geranylgeranyltransferase I is involved in specific aspects of abscisic acid and auxin signaling in Arabidopsis. Plant Physiol 139: 722-733.

Jovanovic Z, Stanisavljevic N, Mikic A, Radovic S, Maksimovic V. 2014. Water deficit down-regulates miR398 and miR408 in pea (Pisum sativum L.). Plant Physiol Biochem 83: 26-31.

Kanazawa M, Terada K, Kato S, Mori M. 1997. HSDJ, a human homolog of DnaJ, is farnesylated and is involved in protein import into mitochondria. J Biochem 121: 890-895.

Kantar M, Lucas SJ, Budak H. 2011. miRNA expression patterns of Triticum dicoccoides in response to shock drought stress. Planta 233: 471-484.

Kitten GT, Nigg EA. 1991. The CaaX motif is required for isoprenylation, carboxyl methylation, and nuclear membrane association of lamin B2. J Cell Biol 113: 13-23.

Langmead B, Trapnell C, Pop M, Salzberg SL. 2009. Ultrafast and memory-efficient alignment of short DNA sequences to the human genome. Genome Biol 10: R25.

Laubinger S, Sachsenberg T, Zeller G, Busch W, Lohmann JU, Ratsch G, Weigel D. 2008. Dual roles of the nuclear cap-binding complex and SERRATE in pre-mRNA splicing and microRNA processing in Arabidopsis thaliana. Proc Natl Acad Sci 105: 8795-8800.

Lee SC, Lan W, Buchanan BB, Luan S. 2009. A protein kinasephosphatase pair interacts with an ion channel to regulate ABA signaling in plant guard cells. Proc Natl Acad Sci 106: 21419-21424.

Lu C, Fedoroff N. 2000. A mutation in the Arabidopsis HYL1 gene encoding a dsRNA binding protein affects responses to abscisic acid, auxin, and cytokinin. Plant cell 12: 2351-2366.

Ma C, Burd S, Lers A. 2015. miR408 is involved in abiotic stress responses in Arabidopsis. Plant J 84: 169-187.

Misselwitz B, Staeck O, Rapoport TA. 1998. J proteins catalytically activate Hsp70 molecules to trap a wide range of peptide sequences. Mol Cell 2: 593-603.
Moffett P, Farnham G, Peart J, Baulcombe DC. 2002. Interaction between domains of a plant NBS-LRR protein in disease resistance-related cell death. EMBO I 21: 4511-4519.

Nishimura N, Hitomi K, Arvai AS, Rambo RP, Hitomi C, Cutler SR, Schroeder JI, Getzoff ED. 2009. Structural mechanism of abscisic acid binding and signaling by dimeric PYR1. Science 326: 1373-1379.

Noel LD, Cagna G, Stuttmann J, Wirthmuller L, Betsuyaku S, Witte CP, Bhat R, Pochon N, Colby T, Parker JE. 2007. Interaction between SGT1 and cytosolic/nuclear HSC70 chaperones regulates Arabidopsis immune responses. Plant Cell 19: 4061-4076.

Northey JG, Liang S, Jamshed M, Deb S, Foo E, Reid JB, McCourt P, Samuel MA. 2016. Farnesylation mediates brassinosteroid biosynthesis to regulate abscisic acid responses. Nat Plants 2: 16114.

Nour-Eldin HH, Hansen BG, Norholm MH, Jensen JK, Halkier BA. 2006. Advancing uracil-excision based cloning towards an ideal technique for cloning PCR fragments. Nucl Acids Res 34: e122.

Obayashi T, Kinoshita K, Nakai K, Shibaoka M, Hayashi S, Saeki M, Shibata D, Saito K, Ohta H. 2007. ATTED-II: a database of co-expressed genes and cis elements for identifying co-regulated gene groups in Arabidopsis. Nucl Acids Res 35: D863-D869.

Ossowski S, Schwab R, Weigel D. 2008. Gene silencing in plants using artificial microRNAs and other small RNAs. Plant 7 53: 674-690.

Park MY, Kim SY. 2014. The Arabidopsis J protein AtJ1 is essential for seedling growth, flowering time control and ABA response. Plant Cell Physiol 55: 2152-2163.

Picard D. 2006. Chaperoning steroid hormone action. Trends Endocrinol Metab 17: 229-235.

Pratt WB, Morishima Y, Osawa Y. 2008. The Hsp90 chaperone machinery regulates signaling by modulating ligand binding clefts. J Biol Chem 283: 22885-22889.

Running MP, Fletcher JC, Meyerowitz EM. 1998. The WIGGUM gene is required for proper regulation of floral meristem size in Arabidopsis. Development 125: 2545-2553.

Running MP, Lavy M, Sternberg H, Galichet A, Gruissem W, Hake S, Ori N, Yalovsky S. 2004. Enlarged meristems and delayed growth in plp mutants result from lack of CaaX prenyltransferases. Proc Natl Acad Sci 101: 7815-7820.

Sainsbury F, Thuenemann EC, Lomonossoff GP. 2009. pEAQ: versatile expression vectors for easy and quick transient expression of heterologous proteins in plants. Plant Biotechnol J7: 682-693.

Salas-Munoz S, Rodriguez-Hernandez AA, Ortega-Amaro MA, Salazar-Badillo FB, Jimenez-Bremont JF. 2016. Arabidopsis AtDjA3 null mutant shows increased sensitivity to abscisic acid, salt, and osmotic stress in germination and post-germination stages. Front Plant Sci 7: 220.

Sangster TA, Queitsch C. 2005. The HSP90 chaperone complex, an emerging force in plant development and phenotypic plasticity. Curr Opin Plant Biol 8: 86-92.

Schirle NT, Sheu-Gruttadauria J, MacRae IJ. 2014. Structural basis for microRNA targeting. Science 346: 608-613.

Sheard LB, Tan X, Mao H, Withers J, Ben-Nissan G, Hinds TR, Kobayashi Y, Hsu FF, Sharon M, Browse J, et al. 2010. Jasmonate perception by inositol-phosphate-potentiated COI1-JAZ coreceptor. Nature 468: 400-405.

Shen L, Kang YG, Liu L, Yu H. 2011. The J-domain protein J3 mediates the integration of flowering signals in Arabidopsis. Plant Cell 23: 499-514. 
Takahashi A, Casais C, Ichimura K, Shirasu K. 2003. HSP90 interacts with RAR 1 and SGT1 and is essential for RPS2-mediated disease resistance in Arabidopsis. Proc Natl Acad Sci 100: 11777-11782.

Tan X, Calderon-Villalobos LI, Sharon M, Zheng C, Robinson CV, Estelle M, Zheng N. 2007. Mechanism of auxin perception by the TIR1 ubiquitin ligase. Nature 446: 640-645.

Wang M, Casey PJ. 2016. Protein prenylation: unique fats make their mark on biology. Nat Rev Mol Cell Biol 17: 110-122.

Wang Y, Ying J, Kuzma M, Chalifoux M, Sample A, McArthur C, Uchacz T, Sarvas C, Wan J, Dennis DT, et al. 2005. Molecular tailoring of farnesylation for plant drought tolerance and yield protection. Plant J 43: 413-424.

Wang Y, Beaith M, Chalifoux M, Ying J, Uchacz T, Sarvas C, Griffiths R, Kuzma M, Wan J, Huang Y. 2009. Shoot-specific downregulation of protein farnesyltransferase ( $\alpha$-subunit) for yield protection against drought in canola. Mol Plant 2: 191-200.

Wang M, Wang Q, Zhang B. 2013. Response of miRNAs and their targets to salt and drought stresses in cotton (Gossypium hirsutum L.). Gene 530: 26-32.

Wang R, Zhang Y, Kieffer M, Yu H, Kepinski S, Estelle M. 2016. HSP90 regulates temperature-dependent seedling growth in Arabidopsis by stabilizing the auxin co-receptor F-box protein TIR1. Nat Commun 7: 10269.

Winter D, Vinegar B, Nahal H, Ammar R, Wilson GV, Provart NJ. 2007. An 'electronic fluorescent pictograph' browser for exploring and analyzing large-scale biological data sets. PLOS One 2: e718.

Wu JR, Wang LC, Lin YR, Weng CP, Yeh CH, Wu SJ. 2017. The Arabidopsis heat-intolerant 5 (hit5)/enhanced response to aba 1 (eral) mutant reveals the crucial role of protein farnesy- lation in plant responses to heat stress. New Phytol 213: 1181-1193.

Yalovsky S, Kulukian A, Rodriguez-Concepcion M, Young CA, Gruissem W. 2000. Functional requirement of plant farnesyltransferase during development in Arabidopsis. Plant Cell 12: 1267-1278.

Yamasaki H, Hayashi M, Fukazawa M, Kobayashi Y, Shikanai T. 2009. SQUAMOSA promoter binding protein-like7 is a central regulator for copper homeostasis in Arabidopsis. Plant cell 21: 347-361.

Zhang FL, Casey PJ. 1996. Protein prenylation: molecular mechanisms and functional consequences. Annu Rev Biochem 65: 241-269.

Zhang JF, Yuan LJ, Shao Y, Du W, Yan DW, Lu YT. 2008. The disturbance of small RNA pathways enhanced abscisic acid response and multiple stress responses in Arabidopsis. Plant Cell Environ 31: 562-574.

Zhang XC, Millet YA, Cheng Z, Bush J, Ausubel FM. 2015. Jasmonate signalling in Arabidopsis involves SGT1b-HSP70 HSP90 chaperone complexes. Nat Plants 1: 15049.

Zhou L, Liu Y, Liu Z, Kong D, Duan M, Luo L. 2010. Genomewide identification and analysis of drought-responsive microRNAs in Oryza sativa. J Exp Bot 61: 4157-4168.

Zhu JK, Bressan RA, Hasegawa PM. 1993. Isoprenylation of the plant molecular chaperone ANJ1 facilitates membrane association and function at high temperature. Proc Natl Acad Sci 90: 8557-8561.

Ziegelhoffer EC, Medrano LJ, Meyerowitz EM. 2000. Cloning of the Arabidopsis WIGGUM gene identifies a role for farnesylation in meristem development. Proc Natl Acad Sci 97: 7633-7638. 


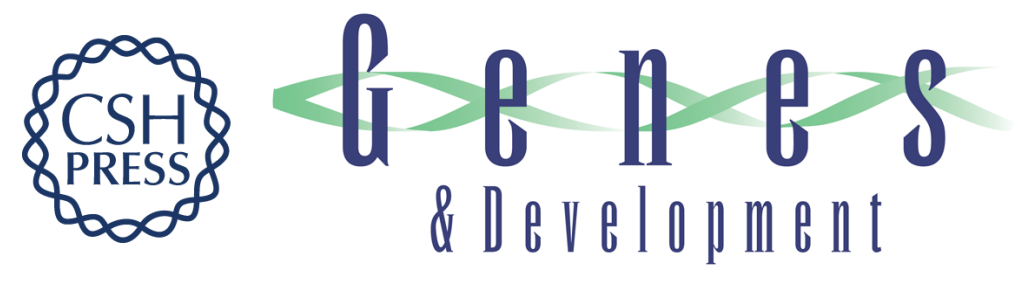

\section{Heat-shock protein 40 is the key farnesylation target in meristem size control, abscisic acid signaling, and drought resistance}

Andrea Barghetti, Lars Sjögren, Maïna Floris, et al.

Genes Dev. 2017, 31: originally published online December 21, 2017

Access the most recent version at doi:10.1101/gad.301242.117

\section{Supplemental http://genesdev.cshlp.org/content/suppl/2017/12/21/gad.301242.117.DC1 Material}

References This article cites 80 articles, 36 of which can be accessed free at: http://genesdev.cshlp.org/content/31/22/2282.full.html\#ref-list-1

Creative This article is distributed exclusively by Cold Spring Harbor Laboratory Press for the first Commons six months after the full-issue publication date (see

License http://genesdev.cshlp.org/site/misc/terms.xhtml). After six months, it is available under a Creative Commons License (Attribution-NonCommercial 4.0 International), as described at http://creativecommons.org/licenses/by-nc/4.0/.

Email Alerting Receive free email alerts when new articles cite this article - sign up in the box at the top Service right corner of the article or click here.

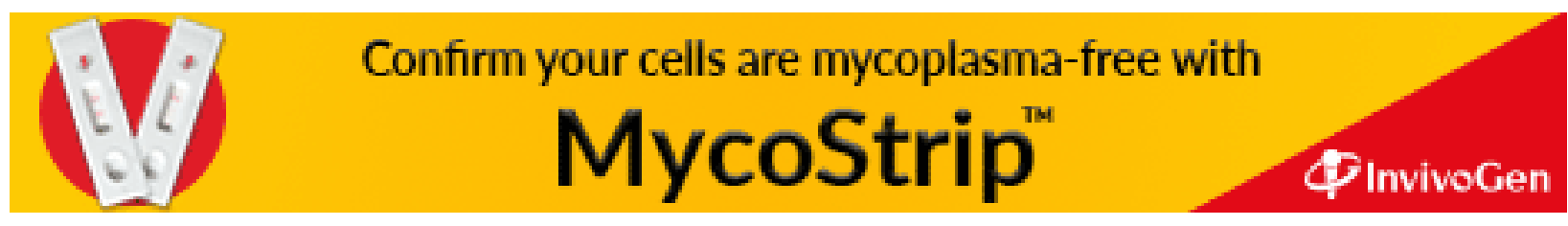

